\title{
Explorer At Large: Pilot Implementation in Ohio Evaluation Report 2019-2020
}

\section{July 2020}

Submitted to:

Explorer At Large,

Little Yud Ventures, Inc.

Prepared by:

Kimberley Preston, Researcher

Kelly Riedinger, Senior Researcher

Martin Storksdieck, Director

STEM Research Center at Oregon State University

Cite as:

Preston, K., Riedinger, K., \& Storksdieck, M. (2020): Explorer At Large Pilot Implementation in Ohio: Evaluation Report 2019-2020. Technical Report. Corvallis, OR: Oregon State University. 


\section{Table of Contents}

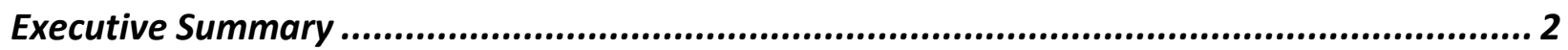

Introduction .................................................................................................................... 5

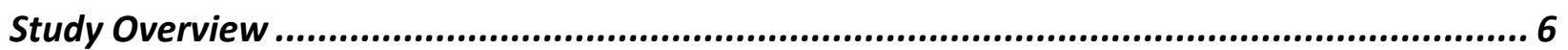

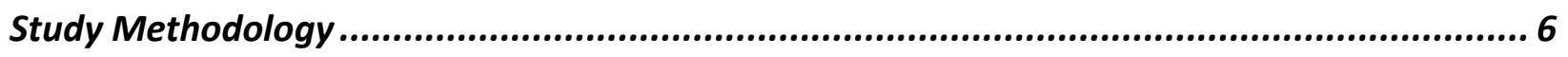

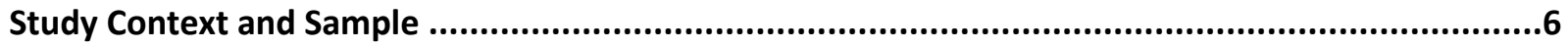

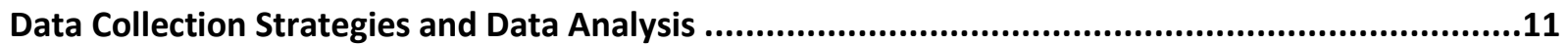

Key Findings from Pilot Implementation ....................................................................... 11

Guiding Question 1: Will Kindergarten and 3rd grade teachers consider XAL instructional units to be to be valuable overall and valuable for student learning, engagement, and question-asking skill

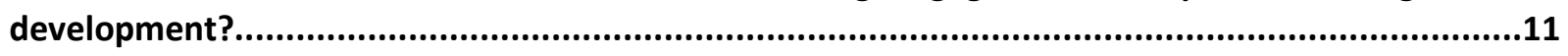

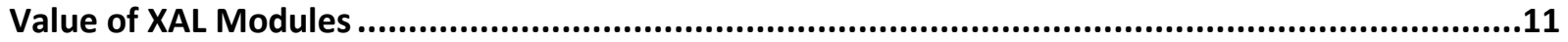

Guiding Question 2: Will Kindergarten and 3rd grade teachers be able to successfully include instructional units of varying length based on one or more XAL videos in their classrooms and in

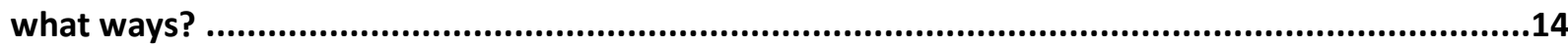

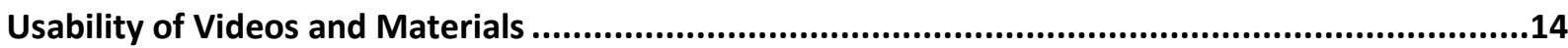

Guiding Question 3: Will Kindergarten and 3rd grade teachers who utilize these instructional units make changes to their own instructional practices and show changes in self-efficacy teaching

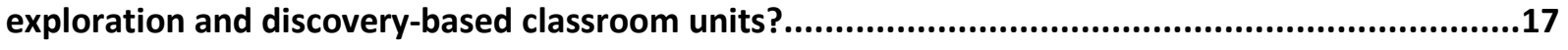

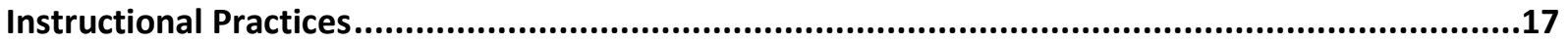

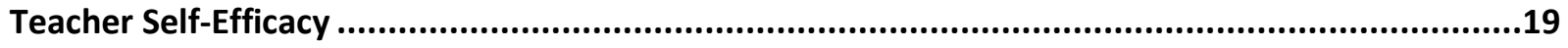

Guiding Question 4: Will teachers report that Kindergarten and 3rd grade students show growth on fundamental measures of affective and cognitive learning associated with the exploratory nature of

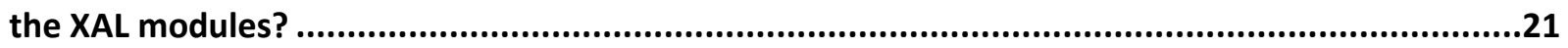

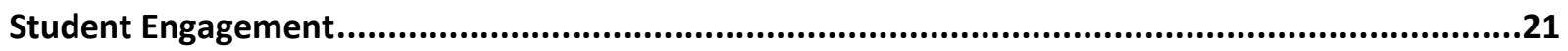

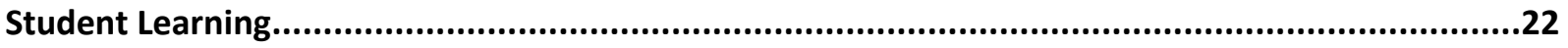

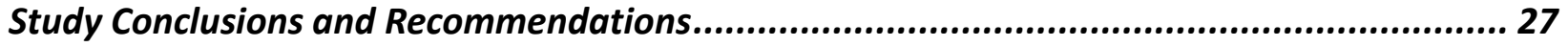

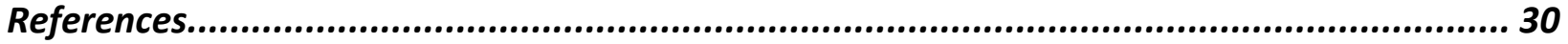

APPENDIX A: Data Collection Instruments........................................................... 31 


\section{Executive Summary}

Explorer At Large (XAL) is an education initiative designed to encourage students and their families to be curious and develop an identity as an explorer. XAL delivers a holistic ecosystem of learning opportunities that model curiosity and exploration skills and consists of the following four primary components: 1) freely distributed videos that invite students to observe exploration; 2) instructional materials (teacher guides, hands-on classroom and outdoor activities) that guide students in practicing exploration; 3) field trips to settings in students' local communities that empower students to experience exploration; and 4) family moments that encourage parent/caregiver engagement and inspires students to share exploration.

This report shares evaluation findings from piloting the XAL instructional materials with $\mathrm{K}$ and $3^{\text {rd }}$ grade teachers and students from schools in Ohio. The report is following up on an earlier pilot that focused on schools in the Columbus region. The evaluation was designed to address the following evaluation questions:

1. Will Kindergarten and 3rd grade teachers consider the XAL instructional units to be valuable overall and valuable for student learning, engagement, and question-asking skill development?

2. Will Kindergarten and 3rd grade teachers be able to successfully include instructional units of varying length based on one or more XAL videos in their classrooms and in what ways?

3. Will Kindergarten and 3rd grade teachers who utilize these instructional units make changes to their own instructional practices and show changes in self-efficacy teaching exploration and discovery-based classroom units?

4. Will teachers report that Kindergarten and 3rd grade students show growth on fundamental measures of affective and cognitive learning associated with the exploratory nature of the XAL modules?

The sample for the evaluation included 28 classrooms from the Columbus and Cleveland area and represented diversity in terms of location, school type, grade level (Kindergarten $\& 3^{\text {rd }}$ grade) and student characteristics. Data collection was comprised of teacher feedback in three forms: A pre-survey (administered at the beginning of the first workshop), a post-survey (administered at the conclusion of the program), and module feedback forms (completed after teachers implemented or reviewed each module). As a result of challenges from the COVID-19 pandemic, the study shifted to a hybrid model of some teachers implementing in an online environment, where possible, and other teachers reviewing the instructional materials and providing their feedback only based on their reviews (rather than also experiencing implementation in their classrooms. This stipulation is noted throughout the report, where appropriate. 


\section{Key Findings:}

Overall the XAL pilot implementation in Ohio was successful and provided students an opportunity to engage with videos and instructional materials to foster their curiosity and identities as explorers. Teachers were generally satisfied with the materials, particularly the videos and classroom instructional materials. The following key findings emerged:

- Teachers generally consider the instructional units to be valuable for their students' engagement ('hands-on' activities) and deeper learning (content knowledge, engaging students in science and engineering practices, and developing their inter/intrapersonal skills).

- XAL modules offered teachers flexibility in how and when they implemented the materials, to meet their needs, with few technical difficulties.

- The Animal Nutrition module received consistently higher value ratings and positive feedback than the other two modules.

- Teachers found that materials and associated activities to be highly engaging for students, especially the videos and materials associated with the Animal Nutrition module.

- Before and after implementing the XAL material, teachers showed some shifts in their instructional practices, as related to certain science topics, lesson preparation/implementation processes, and student engagement.

- Teachers' self-efficacy in supporting science and engineering practices showed significant increase over the course of the XAL program. Teachers showed little shift in their confidence as related to promoting Knowledge-Seeking Skills, engaging students in asking questions or helping students in using mathematical/computational thinking.

- Teachers reported that the modules were generally effective at engaging students with science concepts and teachers reported high levels of student proficiency following implementation of each module.

- For the most part, the materials were successful at engaging students with scientific practices and deeper learning.

\section{Recommendations:}

We offer the following recommendations:

- Continue Developing XAL Content and Material using data and teacher feedback from both evaluation studies, including using Animal Nutrition as an exemplar for continued development of existing and future modules. We also recommend using the evaluation studies to inform ongoing refinement and development of the Family Moments.

- Consider Providing Additional Support for Teachers by taking in to account teachers' feedback and request for more information to build their background knowledge on 
relevant topics for each module. There is also an opportunity to further refine professional development and support materials to continue supporting teachers in fostering student curiosity and developing students' questioning skills.

- Consider Partnering with Teachers as co-creators and co-developers for ensuring content is grade-level appropriate, especially for early elementary learners, and fits with teachers' curriculum especially as XAL is more broadly implemented in new states and contexts.

- Revisit, Reflect and Expand Recruitment Strategies to ensure XAL is successfully as it is more broadly implemented in new contexts. In this iteration of the study, there were recruitment challenges in identifying teachers who were willing to participate and implement the materials in their classrooms. Consider reaching out to teachers who elected not to participate to understand their reasons and develop potential new strategies such as leveraging past participants as teacher 'champions' for disseminating information about XAL to their colleagues and recruiting new classrooms to participate. 


\section{Introduction}

Explorer At Large (XAL) is an education initiative designed to encourage students and their families to be curious and develop an identity as an explorer. XAL delivers a holistic ecosystem of learning opportunities that model curiosity and exploration skills such as asking questions, posing problems, investigating and thinking critically. The XAL ecosystem consists of the following four primary components: 1) freely distributed videos that invite students to observe exploration; 2) instructional materials (teacher guides, hands-on classroom and outdoor activities) that guide students in practicing exploration; 3) field trips to settings in students' local communities that empower students to experience exploration; and 4) family moments that encourage parent/caregiver engagement and inspires students to share exploration. XAL's goal is to engage students with elements of authenticity, real-world exploration, and live-action adventure and to deliver meaningful science content while preparing them for future learning and success in life.

In earlier iterations of the project, XAL developed and tested 35 educational videos with experts and explorers across a variety of institutions. Through the piloting of the videos, XAL identified effective strategies and approaches for developing creative educational videos aligned with PreK-12 curriculum that uses experts to model and encourage questioning, curiosity and exploration in ways that are both highly engaging and entertaining for students.

This was followed up by an implementation phase in which XAL videos and associated instructional materials - including teacher guides, classroom activities, field trips, and family moments - were tested with approximately 600 Kindergarten and 3rd grade students and their teachers across the Columbus, Ohio region. The implementation phase also included an evaluation study implemented by researchers the STEM Research Center at Oregon State University to understand the extent to which the materials could be successfully used by teachers in ways that resulted in intended outcomes for the students.

The study confirmed that the materials fit with teachers' curriculum and classroom instruction and that overall, teachers were able to implement the materials successfully with $\mathrm{K}$ and 3 rd grade students. Teachers indicated high levels of satisfaction with the materials and particularly noted that they found the XAL content highly engaging for students. Student outcomes also included cognitive and affective learning gains including learning key science concepts, engaging with scientific practices such as questioning, enjoyment of science and developing an identity as a learner of science. Implementing the materials also resulted in outcomes for teachers such as changes to their instructional practices and greater self-efficacy for teaching science. The study also revealed areas for continued improvement including building out the ecosystem through continued development of family moments and at-home explorations. 
This report describes findings from the formative evaluation of the current phase of XAL, funded by the Harold C. Schott Foundation, which includes broader implementation in schools across Ohio including the Columbus, Cincinnati and Cleveland metro and surrounding areas.

\section{Study Overview}

This evaluation study builds on findings from the earlier implementation phase and explores with a broader sample the implementation of XAL materials in K \& 3rd grade classrooms in Columbus, Cincinnati and Cleveland. Given the broader focus, the data collection strategies for this phase focused on teacher self-report surveys that extend the findings from the implementation phase evaluation study. The evaluation study was implemented with 10 Kindergarten teachers, 15 3rd grade teachers, and 3 Kindergarten and 3rd grade teachers from 11 schools in Columbus and 5 schools in Cleveland. Due to challenges with recruitment, no schools in Cincinnati were represented. Overall, the study was designed to examine the following research questions:

1. Will Kindergarten and $3^{\text {rd }}$ grade teachers consider the XAL instructional units to be valuable overall and valuable for student learning, engagement, and questions-asking skill development?

2. Will Kindergarten and 3rd grade teachers be able to successfully include instructional units of varying length based on one or more XAL videos in their classrooms and in what ways?

3. Will Kindergarten and 3rd grade teachers who utilize these instructional units make changes to their own instructional practices and show changes in self-efficacy teaching exploration and discovery-based classroom units?

4. Will teachers report that Kindergarten and 3rd grade students show growth on fundamental measures of affective and cognitive learning associated with the exploratory nature of the XAL modules?

\section{Study Methodology}

\section{Study Context and Sample}

The evaluation study of the broader implementation was initially designed to be implemented with schools across three regions in Ohio. Due to challenges with recruitment, participating teachers were only from schools in the Greater Columbus and Cleveland metropolitan areas. These additional regions were selected because they directly build off of the earlier testing in Columbus and leverage existing professional networks through the PAST Foundation and prior teacher participants. Moreover, schools in each of these regions have access to a range of school types - including public, private and parochial schools - as well as school setting including rural, small-town, suburban and urban schools. Each region also offered an opportunity to connect with 
other resources within the learning ecosystem such as local museums, zoos, parks and environmental centers.

Table 1 displays the characteristics of each school and district who had teachers participate in this iteration of the XAL implementation. As demonstrated in the table, the schools represented in the study were diverse in terms of a number of variables including location, setting, schooltype and student population. 
Table 1. Participating Schools

\begin{tabular}{|c|c|c|c|c|}
\hline District & School & Setting & Student Population & $\begin{array}{l}\text { \# of } \\
\text { Teachers }\end{array}$ \\
\hline $\begin{array}{l}\text { Bexley City } \\
\text { Schools }\end{array}$ & Maryland Elementary & Suburban & $\begin{array}{l}\text { Public School } \\
\text { Very Low Student Poverty } \\
\text { and Large Student } \\
\text { Population }\end{array}$ & 4 \\
\hline $\begin{array}{l}\text { Columbus } \\
\text { Catholic } \\
\text { Diocese }\end{array}$ & Saint Mary Columbus & Urban & Parochial School & 1 \\
\hline $\begin{array}{l}\text { Columbus City } \\
\text { Schools }\end{array}$ & $\begin{array}{l}\text { Duxberry Elementary } \\
\text { Indianola Informal K-8 } \\
\text { Columbus Spanish } \\
\text { Immersion Academy }\end{array}$ & Urban & $\begin{array}{l}\text { Public School } \\
\text { Very High Student Poverty } \\
\text { and Very Large Student } \\
\text { Population }\end{array}$ & 7 \\
\hline $\begin{array}{l}\text { Hilliard City } \\
\text { Schools }\end{array}$ & Darby Creek & Suburban & $\begin{array}{l}\text { Public School } \\
\text { Very Low Student Poverty } \\
\text { and Large Student } \\
\text { Population }\end{array}$ & 1 \\
\hline $\begin{array}{l}\text { Noble } \\
\text { Academy } \\
\text { Columbus }\end{array}$ & Noble Academy Columbus & $\begin{array}{l}\text { K-8 Public } \\
\text { Charter } \\
\text { School }\end{array}$ & Charter School & 2 \\
\hline $\begin{array}{l}\text { Red Oak } \\
\text { Community } \\
\text { School }\end{array}$ & $\begin{array}{l}\text { Red Oak Community } \\
\text { School }\end{array}$ & Urban & $\begin{array}{l}\text { Charter School that focuses } \\
\text { on Nature Immersion }\end{array}$ & 2 \\
\hline $\begin{array}{l}\text { Southwestern } \\
\text { City Schools }\end{array}$ & Finland Elementary School & Urban & $\begin{array}{l}\text { Public School } \\
\text { High Student Poverty and } \\
\text { Average Student Population }\end{array}$ & 2 \\
\hline $\begin{array}{l}\text { Sunrise } \\
\text { Academy }\end{array}$ & Charter school & Suburban & Charter School & 1 \\
\hline $\begin{array}{l}\text { Upper } \\
\text { Arlington }\end{array}$ & Tremont Elementary & Suburban & $\begin{array}{l}\text { Public School } \\
\text { Very Low Student Poverty } \\
\text { and Large Student } \\
\text { Population }\end{array}$ & 2 \\
\hline $\begin{array}{l}\text { Cleveland } \\
\text { Municipal } \\
\text { District }\end{array}$ & $\begin{array}{l}\text { Warner Girls' Leadership } \\
\text { Academy }\end{array}$ & Urban & $\begin{array}{l}\text { Private School } \\
\text { Very High Student Poverty } \\
\text { and Very Large Student } \\
\text { Population }\end{array}$ & 1 \\
\hline $\begin{array}{l}\text { Catholic } \\
\text { Diocese of } \\
\text { Cleveland }\end{array}$ & $\begin{array}{l}\text { Saint Anselm School } \\
\text { St. Anthony of Padua } \\
\text { All Saints of St. John } \\
\text { Vianney } \\
\text { St. Leo the Great }\end{array}$ & $\begin{array}{l}\text { Urban and } \\
\text { Suburban }\end{array}$ & Parochial School & 5 \\
\hline
\end{tabular}

Through the pre-survey, administered at the beginning of the first workshop, we gathered descriptive information about the teachers and students in this cohort. Shown in Table 2, 43\% of teachers in the cohort have between 11 and 20 years of teaching experience. There were slightly more $3^{\text {rd }}$ grade classrooms (54\%) than Kindergarten classrooms (36\%) represented and three teachers who implemented the modules for both $\mathrm{K}$ and $3^{\text {rd }}$ graders. Most classrooms contained 
between 21 and 30 students, with majority of teachers reporting that less than $14 \%$ of their students are English Language Learners and less than $14 \%$ of their students are qualified for free/reduced lunch. The majority of teachers reported that fewer than $9 \%$ of their students are identified as special needs or special education students. Of the 28 teachers, 4 reported previously participating in a PAST Foundation professional development opportunity and of those 4, 3 teachers had attended only 1 workshop or meeting and 1 teacher had attended 2 workshops or meetings. The demographic data demonstrates that the sample for the study was diverse across a number of variables, as depicted in Tables 1 and 2 . 
Table 2. Teacher and student characteristics

\begin{tabular}{|c|c|c|}
\hline Characteristic & Category & Total \\
\hline \multirow[t]{6}{*}{ Years of Teaching Experience } & & 28 \\
\hline & 1 to 2 years & 5 \\
\hline & 3 to 5 years & 1 \\
\hline & 6 to 10 years & 5 \\
\hline & 11 to 20 years & 12 \\
\hline & More than 20 years & 5 \\
\hline \multirow[t]{4}{*}{ Grade Level } & & 28 \\
\hline & Kindergarten & 10 \\
\hline & $3^{\text {rd }}$ grade & 15 \\
\hline & Kindergarten and $3^{\text {rd }}$ grade & 3 \\
\hline \multirow[t]{5}{*}{ Number of Students } & & 26 \\
\hline & 11 to 20 & 7 \\
\hline & 21 to 30 & 16 \\
\hline & 31 to 40 & 2 \\
\hline & 41 to 50 & 1 \\
\hline \multirow[t]{8}{*}{ Percent of English Language Learners } & & 28 \\
\hline & None & 12 \\
\hline & 1 to $14 \%$ & 7 \\
\hline & 15 to $29 \%$ & 1 \\
\hline & 30 to $44 \%$ & 3 \\
\hline & 45 to $59 \%$ & 3 \\
\hline & 60 to $99 \%$ & 0 \\
\hline & $100 \%$ & 2 \\
\hline \multirow{10}{*}{$\begin{array}{l}\text { Percent of Students Qualified for Free/Reduced } \\
\text { Lunch }\end{array}$} & & 28 \\
\hline & None & 5 \\
\hline & 1 to $14 \%$ & 10 \\
\hline & 15 to $29 \%$ & 1 \\
\hline & 30 to $44 \%$ & 0 \\
\hline & 45 to $59 \%$ & 2 \\
\hline & 60 to $74 \%$ & 0 \\
\hline & 75 to $89 \%$ & 2 \\
\hline & 90 to $99 \%$ & 2 \\
\hline & $100 \%$ & 6 \\
\hline \multirow{7}{*}{$\begin{array}{l}\text { Percent of Students Identified as Special Needs } \\
\text { or Special Education Students }\end{array}$} & & 28 \\
\hline & None & 8 \\
\hline & 1 to $9 \%$ & 9 \\
\hline & 10 to $19 \%$ & 5 \\
\hline & 20 to $29 \%$ & 5 \\
\hline & 30 to $39 \%$ & 0 \\
\hline & $40 \%$ & 1 \\
\hline \multirow{3}{*}{$\begin{array}{l}\text { Participated in a prior PAST PD workshop or } \\
\text { online meeting }\end{array}$} & & 28 \\
\hline & No & 24 \\
\hline & Yes & 4 \\
\hline \multirow{3}{*}{$\begin{array}{l}\text { Of Those Who Participated in PAST PD, How } \\
\text { Many? }\end{array}$} & & 4 \\
\hline & 1 workshop or meeting & 3 \\
\hline & 2 workshops or meetings & 1 \\
\hline
\end{tabular}




\section{Data Collection Strategies and Data Analysis}

Data collection was comprised of teacher feedback in three forms: A pre-survey (administered at the beginning of the first workshop), a post-survey (administered at the conclusion of the program), and module feedback forms (completed after teachers implemented or reviewed each module). The surveys and feedback forms contained a combination of closed-ended (e.g. ranked scale) and open-ended prompts.

During the implementation period, the COVID-19 global pandemic resulted in school closures for the remainder of the Spring term across Ohio and Nationwide. The original intent for implementing the XAL instructional module necessarily had to be adjusted. Before the shutdown, nearly all of the teachers had implemented the Pollinator module with their students. After multiple discussions across the team and in conversation with teachers, a decision was made to encourage teachers to implement the remaining two modules - Animal Nutrition and Waterways - if possible or to at least review and provide feedback on the module feedback surveys. Data tables and visualizations throughout the report indicate where the data provided represents feedback by a teacher who implemented versus only reviewed.

The teacher pre/post surveys and module feedback forms were administered through the online platform Qualtrics. Quantitative data were analyzed in Excel spreadsheets (e.g. descriptive statistics, mean scores) and SPSS (e.g. comparison from pre and post surveys). Qualitative data were analyzed using inductive, thematic coding.

\section{Key Findings from Pilot Implementation}

In the key findings section below, we compile, analyze and report findings from teacher feedback to address the guiding questions of this study.

Guiding Question 1: Will Kindergarten and 3rd grade teachers consider XAL instructional units to be to be valuable overall and valuable for student learning, engagement, and questionasking skill development?

This first guiding question aims to better understand whether or not teachers find value in the XAL instructional units generally and more specifically as related to student growth.

\section{Value of XAL Modules}

To assess the extent to which teachers value the XAL materials overall, teachers were asked a series of three questions at the conclusion of the pilot program, including how valuable the XAL materials are, how likely they would be to use the XAL material in the future and how likely they would be to recommend the XAL material to a colleague, measured on a 10-point scale. The responses to these prompts allowed us to eventually calculate the 'Net Promoter Score' which is a validated metric for measuring user satisfaction. 
The three ratings for each respondent were averaged then sorted into categories. As shown in Figure 1, a score of 0-6 is a 'Detractor', 7-8 is a 'Passive', and 9-10 is a 'Promoter'. Respondents that fall into the 'Detractors' category indicated dissatisfaction with the materials and may share their dissatisfaction with others. Those that are considered 'Passive,' indicates satisfaction with the material but that the individual is not likely to actively promote the material to others. Scores indicating 'Promoters' means they had a positive experience with the material and are more likely than those in the 'Passive' category to actively promote the material to others.

Figure 1. Net promoter scores and categories.

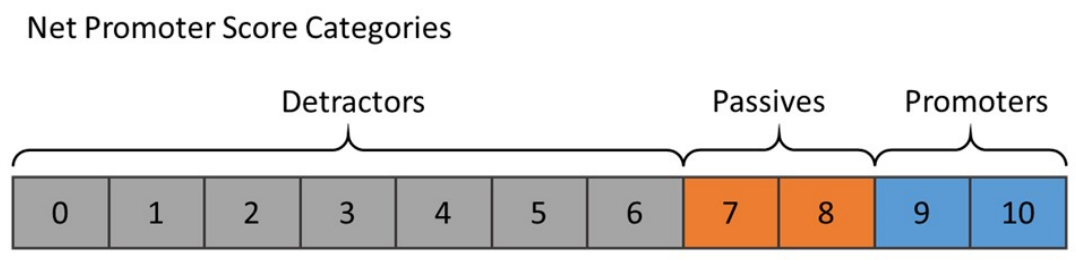

Figure 2 shows the distribution of overall Promoter ratings provided by teachers when averaged across the three instructional modules. Overall, a majority of teachers were considered Promoters indicating that they were satisfied with the materials, likely to use them again and likely to recommend the materials to their colleagues.

Figure 2. Distribution of Promoter ratings from the XAL material overall

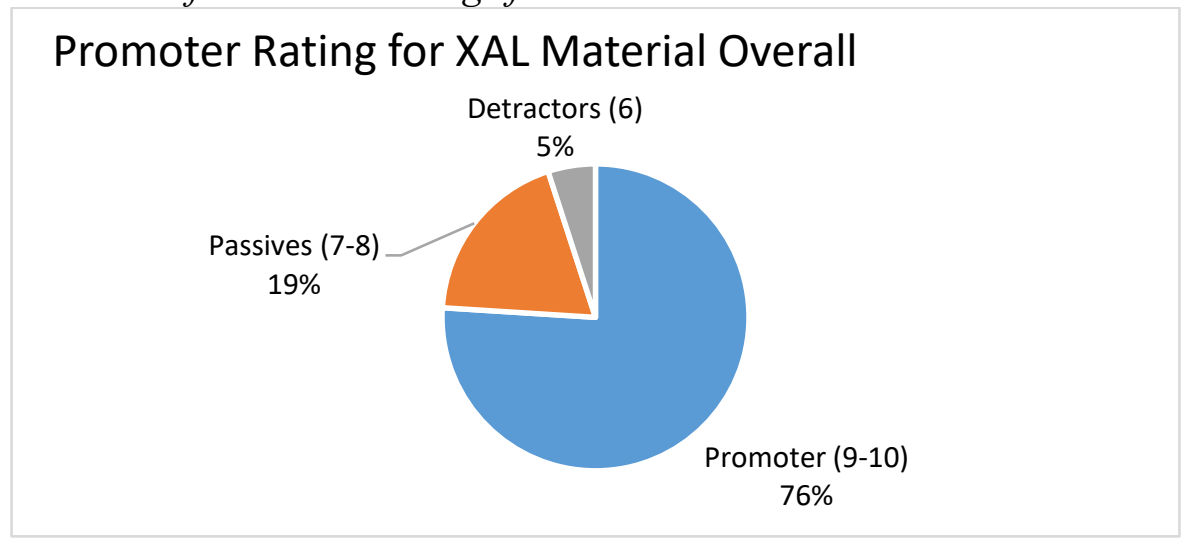

To calculate the Net Promoter Score, we took the percentage of Promoters subtracted by the percentage of Detractors. Table 3 highlights Net Promoter Scores for each of the instructional modules and the scores are further separated by teachers who were able to implement the modules with students (either in-person or virtually) and by teachers who were only able to review the materials. As displayed in the table, all of the scores across the modules are positive ( +21 or higher), which is interpreted as a "good" score with more teachers promoting the 
materials than not. The Animal Nutrition module overall was rated much higher $(+80)$ as compared to the other two modules with notably higher ratings for teachers who implemented the materials $(+88)$ as compared to teachers who were only able to review $(+50)$.

Table 3. Net promoter scores (scale -100 to $+100^{1}$ ) and average promotor scores (1-10) for modules implemented, reviewed, and overall.

\begin{tabular}{|l|l|l|l|}
\hline & Pollinators & Animal Nutrition & Waterways \\
\hline Implemented & $\mathbf{N}=\mathbf{2 6}$ & $\mathbf{N}=\mathbf{1 6}$ & $\mathbf{N}=\mathbf{1 3}$ \\
Net Promoter & +35 & +88 & +30 \\
Average Rating & 8.1 & 9.3 & 8.1 \\
\hline Reviewed & $\mathbf{N}=\mathbf{0}$ & $\mathbf{N}=\mathbf{4}$ & $\mathbf{N}=\mathbf{6}$ \\
Net Promoter & $\mathrm{N} / \mathrm{A}$ & +50 & 0 \\
Average Rating & N/A & 8.5 & 7.7 \\
\hline Overall & $\mathbf{N}=\mathbf{2 6}$ & $\mathbf{N}=\mathbf{2 0}$ & $\mathbf{N}=\mathbf{1 9}$ \\
Net Promoter & +35 & +80 & +21 \\
Average Rating & 8.1 & 9.1 & 8.0 \\
\hline
\end{tabular}

Teachers were also asked a series of questions on the module feedback form that prompted them to reflect on and rate potential outcomes for students. Table 4 provides the data from these survey questions and teachers provided overall high ratings (rating of 4 or higher across all items on each module). The Animal Nutrition module was rated particularly high by teachers for engaging students, which was also reflected in earlier findings from the pilot implementation study.

\footnotetext{
${ }^{1}$ A positive NPS is generally interpreted as good because it indicates that overall, there are more promoters than passives or detractors. Scores above 50 are interpreted as excellent and over 70 is considered exceptional.
} 
Table 4. Average rating from XAL material feedback (5-point scale)

\begin{tabular}{|l|l|l|l|}
\hline & Pollinators & $\begin{array}{l}\text { Animal } \\
\text { Nutrition }\end{array}$ & Waterways \\
\hline Implemented & $\mathbf{n = 2 6}$ & $\mathbf{n = 1 6}$ & $\mathbf{n = 1 3}$ \\
\hline $\begin{array}{l}\text { The module helped students learn key scientific } \\
\text { concepts. }\end{array}$ & 4.31 & 4.67 & 4.15 \\
\hline The module was engaging for my students. & 4.50 & 4.80 & 4.38 \\
\hline The module developed students' questioning. & 4.08 & 4.20 & 4.00 \\
\hline Reviewed & $\mathbf{n}=\mathbf{0}$ & $\mathbf{n}=\mathbf{4}$ & $\mathbf{n}=\mathbf{6}$ \\
\hline $\begin{array}{l}\text { The module would help students learn key } \\
\text { scientific concepts. }\end{array}$ & N/A & 5.00 & 4.50 \\
\hline The module would be engaging for my students. & N/A & 5.00 & 4.00 \\
\hline $\begin{array}{l}\text { The module would develop students' questioning } \\
\text { skills. }\end{array}$ & N/A & 4.50 & 4.00 \\
\hline Overall & $\mathbf{n}=\mathbf{2 6}$ & $\mathbf{n}=\mathbf{2 0}$ & $\mathbf{n = 1 9}$ \\
\hline $\begin{array}{l}\text { The module helped/would help students learn key } \\
\text { scientific concepts. }\end{array}$ & 4.31 & 4.75 & 4.26 \\
\hline $\begin{array}{l}\text { The module was/would be engaging for my } \\
\text { students. }\end{array}$ & 4.50 & 4.85 & 4.26 \\
\hline $\begin{array}{l}\text { The module developed/would develop students' } \\
\text { questioning skills. }\end{array}$ & 4.08 & 4.30 & 4.00 \\
\hline
\end{tabular}

The current evaluation study, coupled with findings from the earlier pilot implementation, suggest that the XAL content has been effective at achieving cognitive and affective outcomes for students related to learning key science outcomes, engaging students and developing students' questioning skills. While the results are generally positive, it is important to note that teachers generally rated "questioning" lower (4.1 on a scale from 1-5) as compared to learning key scientific concepts and student engagement. This suggests a potential area for further developing materials to continued encouraging student curiosity and questioning skills.

\section{Guiding Question 2: Will Kindergarten and 3rd grade teachers be able to successfully include instructional units of varying length based on one or more XAL videos in their classrooms and in what ways?}

We aim to better understand the usability of the XAL videos and material (including ease of use) and in what ways teachers used the material.

\section{Usability of Videos and Materials}

As noted in Table 5, most teachers made at least some changes to the module when they implemented the materials in their classrooms. This suggests that the materials offer flexibility so that teachers can adapt the content to meet the specific needs of the classrooms and students. 
Table 5. Teachers implemented or reviewed the modules to different extents.

\begin{tabular}{|c|c|c|c|}
\hline Use the Module as Suggested? & Pollinators & $\begin{array}{l}\text { Animal } \\
\text { Nutrition }\end{array}$ & Waterways \\
\hline \multicolumn{4}{|l|}{ Implemented } \\
\hline Implemented entire module as suggested & 6 & 3 & 3 \\
\hline Implemented a portion, but as suggested & 14 & 7 & 5 \\
\hline Implemented but made changes & 6 & 6 & 5 \\
\hline \multicolumn{4}{|l|}{ Reviewed } \\
\hline $\begin{array}{l}\text { Likely would have used the entire module as } \\
\text { suggested }\end{array}$ & N/A & 2 & 0 \\
\hline Likely would have used only portion as suggested & N/A & 1 & 5 \\
\hline Likely would have made changes & $\mathrm{N} / \mathrm{A}$ & 1 & 1 \\
\hline Total & 26 & 20 & 18 \\
\hline
\end{tabular}

Table 6 through 8 show when teachers used the videos throughout the module while also noting the number of hours teachers spent using the materials in the classroom ${ }^{2}$. The highlighted values illustrate that most teachers are using the video content at the beginning of the unit. This resonates with findings from the previous study and suggests that teachers may use the videos to introduce the topic or to excite and motive students at the beginning of the unit (Figure 3 ). Teachers are also using the videos throughout the unit to continuously engage students, to explain concepts and to prompt reflection. Teachers are spending, on average, 7.5 hours implementing each module with their students. This finding is promising given that many elementary teachers have only a few hours per week allocated for teaching science.

Table 6. Pollinators Module Usage

\begin{tabular}{|c|c|c|}
\hline \multicolumn{3}{|l|}{ POLLINATORS } \\
\hline $\begin{array}{l}\text { When were videos used during } \\
\text { implementation of the module? }\end{array}$ & $\begin{array}{l}\text { Smithsonian Institute } \\
\text { Gardens }(n=14)\end{array}$ & Orchids $(n=23)$ \\
\hline Beginning & $57 \%$ & $39 \%$ \\
\hline Middle & $21 \%$ & $52 \%$ \\
\hline End & $14 \%$ & $0 \%$ \\
\hline Continuously & $7 \%$ & $9 \%$ \\
\hline
\end{tabular}

\footnotetext{
${ }^{2}$ Note, this data reflects feedback only from those teachers who were able to implement the modules with students and the sample is higher for Pollinators (pre-pandemic) as compared to Animal Nutrition and Waterways (during the pandemic).
} 
Table 7. Animal Nutrition Module Usage

\begin{tabular}{|l|l|l|l|l|l|}
\hline ANIMAL NUTRITION \\
\hline $\begin{array}{l}\text { When were videos used } \\
\text { during implementation of } \\
\text { the module? }\end{array}$ & $\begin{array}{l}\text { Lion } \\
\text { Nutrition } \\
=7)\end{array}$ & $\begin{array}{l}\text { Lion Poop } \\
(\mathrm{n}=7)\end{array}$ & $\begin{array}{l}\text { Panda } \\
\text { Nutrition } \\
=15)\end{array}$ & $\begin{array}{l}\text { Panda Poop } \\
(\mathrm{n}=14)\end{array}$ & $\begin{array}{l}\text { Poop } \\
\text { Analysis (n } \\
4)\end{array}$ \\
\hline Beginning & $\mathbf{7 1 \%}$ & $\mathbf{5 7 \%}$ & $\mathbf{6 7 \%}$ & $\mathbf{6 4 \%}$ & $25 \%$ \\
\hline Middle & $14 \%$ & $43 \%$ & $20 \%$ & $29 \%$ & $25 \%$ \\
\hline End & $0 \%$ & $0 \%$ & $7 \%$ & $7 \%$ & $\mathbf{5 0 \%}$ \\
\hline Continuously & $14 \%$ & $0 \%$ & $7 \%$ & $0 \%$ & $0 \%$ \\
\hline
\end{tabular}

Table 8. Waterways Module Usage

\begin{tabular}{|c|c|c|c|c|}
\hline \multicolumn{5}{|l|}{ WATERWAYS } \\
\hline $\begin{array}{l}\text { When were videos used } \\
\text { during implementation of } \\
\text { the module? }\end{array}$ & $\begin{array}{l}\text { Electrofishing }(n= \\
\text { 4) }\end{array}$ & $\begin{array}{l}\text { Catfish Surgery } \\
(\mathrm{n}=3)\end{array}$ & $\begin{array}{l}\text { Crab Tagging }(n= \\
\text { 7) }\end{array}$ & $\begin{array}{l}\text { Seining (n } \\
=9)\end{array}$ \\
\hline Beginning & $25 \%$ & $67 \%$ & $29 \%$ & $67 \%$ \\
\hline Middle & $50 \%$ & $33 \%$ & $57 \%$ & $11 \%$ \\
\hline End & $0 \%$ & $0 \%$ & $14 \%$ & $22 \%$ \\
\hline Continuously & $25 \%$ & $0 \%$ & $0 \%$ & $0 \%$ \\
\hline
\end{tabular}


Figure 3. How or for what purposes were the videos used during the implantation of the module?

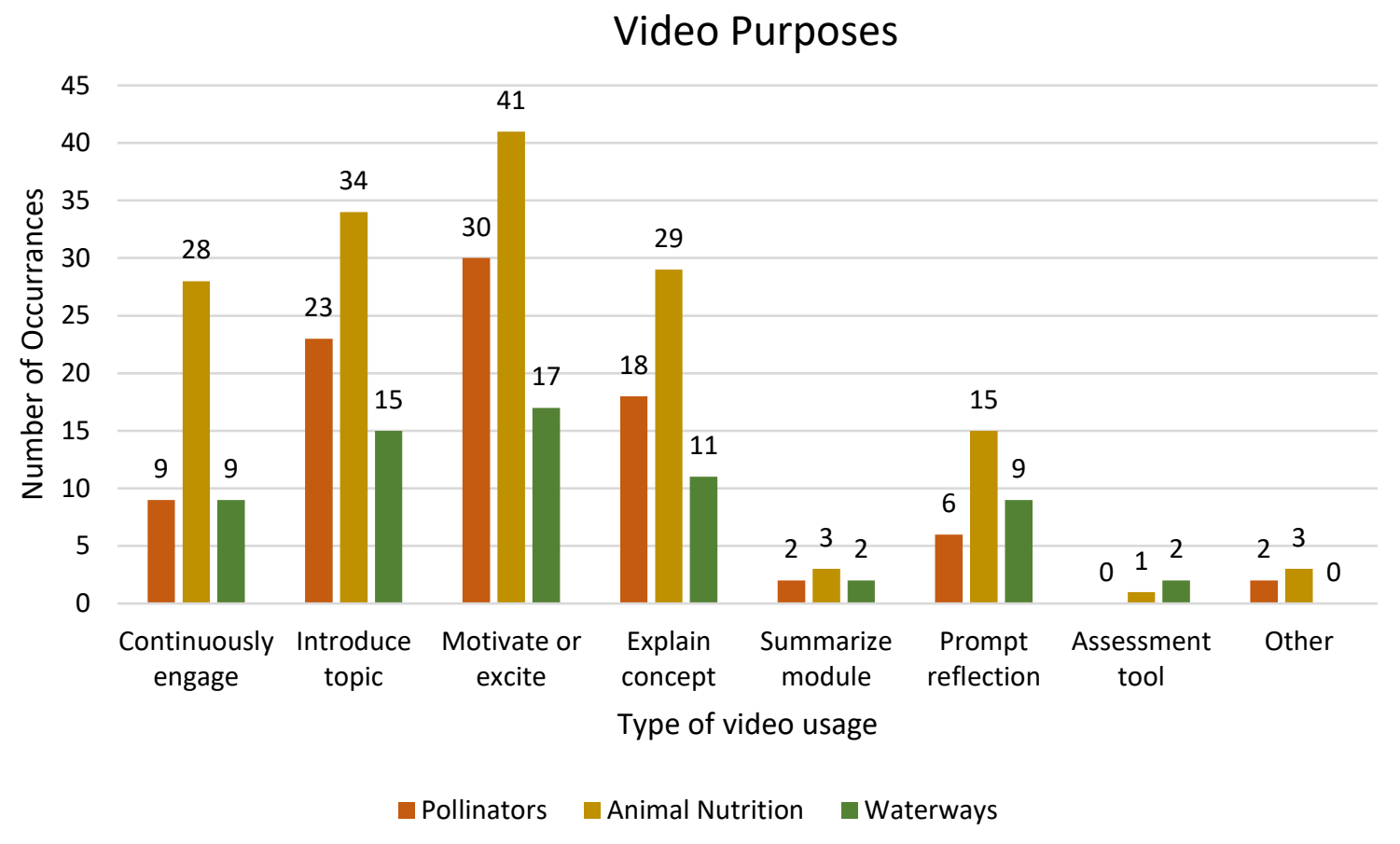

Overall, the majority of teachers had no technical difficulties (76\%). Of those who reported some technical difficulties, the most common issue was slow video loading or the video froze during viewing.

\section{Guiding Question 3: Will Kindergarten and 3rd grade teachers who utilize these instructional units make changes to their own instructional practices and show changes in self-efficacy teaching exploration and discovery-based classroom units?}

\section{Instructional Practices}

Teachers were asked to describe how, if at all, their instructional practices while implementing the XAL modules differed from their normal instructional practices. Across all three modules, roughly a quarter of responses indicated no shift in or that it reinforced their pedagogy (e.g. "Pretty similar because a lot of my lessons are hands-on") and majority of the responses indicated a slight shift in teacher's pedagogy in the form of one of these three general themes: curriculum connections, process, student engagement.

Some teachers describe that the topics covered in the modules were not typically included in their standard curriculum and that the materials prompted them to make connections across the curriculum. From science in general to specific topics, the XAL modules prompted some teachers to re-envision how science topics fit within their curriculum. 
"We don't normally spend this much time on science in a normal school week...It made me realize that science is so much more than worksheets and reading."

"In general, we operated as we normally do, but the activities in this module definitely inspired me to group together standards across the curriculum that I had not in the past."

"I had not made connections on my own as to how the curriculum could connect to something like waterways, and this showed me many possibilities!"

Some teachers reflected on the processes involved in lesson preparation and implementation and shared deviation from their usual processes. For instance, on the front end of implementing the XAL modules, some teachers reflected that the modules prompted cross-classroom collaboration, while others reflected on their personal preparation processes.

The modules "brought our two classes together and helped us do a more in-depth science lesson."

"I had to dedicate more time to research, prep and design more than I normally do"

"I always want to incorporate design and STEM opportunities but am not always [able]

to find the time. This allowed me the time and structure needed to do so successfully."

Many teachers noted that the modules changed aspects of student engagement with the topic and changes in how they, as teachers, engaged with their students. For example, multiple teachers describe that the modules built in more opportunities for students to be creative and explore than the teachers would usually incorporate in their lesson design. Also, a few teachers described that the modules brought to light or reinforced the idea of student-led learning.

"The investigations were much more in-depth and time consuming than I would normally practice...but the children were able to have time to delve into the activities and into their own learning."

"Providing students with time to investigate, design, and build in the classroom would be a bit different than what the students are used to normally doing in the classroom"

"Using the modules changed my instruction by having students explore rather than tell them everything. It allowed them to share their thoughts and ideas." 
"I think this module matches my style as a teacher, which is to be a facilitator of the learning that is happening in the room. I think this module helps me strengthen my own questioning skills and encourage students to ask their own questions."

The challenges associated with shifting mid-year, from in-person learning to distance learning were apparent in some teacher reflections as well.

"Trying to get students to do the activity and then send me pictures of what they were doing was difficult. Keeping 25 students on task when I couldn't 'walk' the room was also a challenge."

"I thought it would not go as good as it was, because of the challenge to teach virtually to kindergarteners, but I was impressed of the response of my students."

\section{Teacher Self-Efficacy}

In the pre-and post-implementation surveys, teachers were asked to reflect on aspects of their self-efficacy, including their confidence in performing certain tasks associated with the XAL modules, before and after implementing the modules. Specifically, the tasks related to promoting students to engage in self-regulated learning or knowledge seeking formed the scale called 'Knowledge-Seeking Skills' while tasks related to teaching STEM skills were combined to form the 'Next Generation Science Standards (NGSS) Science and Engineering Practices' scale. Teachers were asked to rate their confidence in each item from " 1 - Cannot do at all" to " 5 Highly certain I can do it" for each indicator. A total of 21 teachers completed both the pre-and post-surveys and are included in this particular analysis.

Table 9 displays the differences in mean teacher confidence in teaching across the KnowledgeSeeking Skills and NGSS Science and Engineering Practices scales before and after implementing the XAL modules overall and also shows mean differences of the specific indicators included in each scale. The results of a paired samples t-test shows that teachers' mean confidence in teaching Knowledge-Seeking Skills increased slightly after implementing the modules (from 4.59 to 4.64 ) but the difference between pre-implementation and post is not statistically significant. While teachers' confidence in promoting Knowledge-Seeking Skills was fairly high overall (between 4.38 and 4.71), indicators such as teacher confidence in Encouraging Students to Explore showed no change and teacher confidence in Fostering Students' Curiosity showed a slight decrease after implementing the XAL modules. This suggests an area for further development, to support teachers in facilitating student exploration and curiosity.

For the second scale, the results of a paired samples t-test shows that overall, teachers' mean confidence in teaching NGSS Science and Engineering Practices increased after implementing 
the modules (from 4.01 to 4.46 ) and the difference is statistically significant. When looking at the specific indicators within this scale, 6 of the 8 indicators show a statistically significant difference in teacher confidence before and after implementation. This finding is encouraging, considering the XAL materials were designed to tie in with NGSS and conveys that the XAL program supports teachers in engaging students with science and engineering practices. However, two indicators in the NGSS Science and Engineering Practices scale, Engaging Students in Asking Questions and Helping Students in Using Mathematical and Computational Thinking, show little to no change. This indicates while the XAL program did not detract from teachers' confidence in supporting students in these areas, neither did it bolster teachers' confidence, suggesting an area for continued improvement.

Table 9. Differences in teacher confidence before and after implementing XAL modules $(n=21)$

\begin{tabular}{|lccc|}
\hline & $\begin{array}{c}\text { Mean } \\
\text { Pre-Score }\end{array}$ & $\begin{array}{c}\text { Mean } \\
\text { Post-Score }\end{array}$ & $\begin{array}{c}\text { Difference } \\
\text { of Means }\end{array}$ \\
\hline Knowledge-Seeking Skills (overall scale) & $\mathbf{4 . 5 9}$ & $\mathbf{4 . 6 4}$ & $\mathbf{0 . 0 5}$ \\
Encouraging students to be persistent & 4.62 & 4.71 & 0.09 \\
Motivating students & 4.62 & 4.67 & 0.05 \\
Fostering students' curiosity & 4.71 & 4.67 & -0.04 \\
Encouraging students to explore & 4.67 & 4.67 & 0.00 \\
Encouraging students' creativity & 4.67 & 4.71 & 0.04 \\
Encouraging students to think critically & 4.48 & 4.57 & 0.09 \\
Helping students take control of their learning & 4.38 & 4.48 & 0.10 \\
NGSS Science and Engineering Practices*(overall scale) & $\mathbf{4 . 0 1}$ & $\mathbf{4 . 4 6}$ & $\mathbf{0 . 4 5}$ \\
Engaging students in asking questions & 4.38 & 4.38 & 0.00 \\
Helping students in developing and using models* & 3.81 & 4.48 & 0.67 \\
Helping students in planning and carrying out & & & \\
investigations* & 3.81 & 4.48 & 0.67 \\
Assisting students in analyzing and interpreting data* & 4.05 & 4.57 & 0.52 \\
Helping students in using mathematics and & & & \\
computational thinking & 4.33 & 4.38 & 0.05 \\
Encouraging students to construct explanations* & 4.00 & 4.57 & 0.57 \\
Encouraging students to engage in argument from & & & \\
evidence* & 3.76 & 4.29 & 0.53 \\
Encouraging students to obtain, evaluate and & & & \\
communicate information* & 3.90 & 4.52 & 0.62 \\
\hline
\end{tabular}

* The mean difference is significant at $p<.05$

In the final survey, teachers had the opportunity to share final thoughts about their experience using the XAL videos and instructional modules. One teacher shared final thoughts related to his or her self-efficacy as an educator:

"My confidence level grew in regard to building a growth mindset, assisting students through their questioning, and developing models through collaboration. I love that I can learn from my students. I was able to better understand their thought process because I had already had the same experiences with my peers." 


\section{Guiding Question 4: Will teachers report that Kindergarten and 3rd grade students show growth on fundamental measures of affective and cognitive learning associated with the exploratory nature of the XAL modules?}

The fourth guiding question aims to better understand whether or not the XAL modules are engaging for students and in support of learning as reported from teachers' professional assessment.

\section{Student Engagement}

Overall, teachers reported that students showed favorable engagement with the modules. As previously reported in Table 4, all three modules rated 4.26 or above (on a scale from 1-5) in student engagement, with Animal Nutrition and Pollinators showing the highest ratings (4.85 and 4.50 , respectively). Teachers had the opportunity to share in what ways their students benefitted from the modules and share examples of how, if at all, the modules helped students engage. In responses from the broader question of how students may have benefitted from the modules, the majority of comments included mention of the 'hands-on' nature of the activities or that students were 'engaged' in the learning experience, particularly in reference to the Pollinators and Animal Nutrition modules.

"They were so engaged and loved all the hands-on projects!"

"I think that the hands-on activities helped my students to engage with the topic and better understand the concept of pollinators."

"Students whom I normally need to nudge repeatedly to stay on task were some of the most focused during the modules."

When specifically asked to elaborate on how the modules engaged students, the majority of teachers indicated that students were excited by the topics, activities, and opportunity to explore, across all three modules.

"They asked each day to keep working on their projects! And I heard them talking about it during recess time."

"My students were SO excited and engaged. Each day they asked if they got to do more flower explorations."

"My students were excited when it was time to become an explorer in our explorer lab." 
A small number of teachers who implemented the modules via distance learning shared that they had trouble tracking metrics, such as student engagement remotely. However, a number of teachers who implemented via distance learning noted that they did receive some feedback, specifically positive feedback from parents ${ }^{3}$ or from students.

"Albeit, students were at home and I have absolutely no clue as to how much work some of them did. . ."

"Positive feedback from parents (distance learning). Students were very excited to share their creations during Zoom meetings."

"Distance learning was new to us and I received more student responses and work from these activities than anything else we have provided them with. Clearly this was more engaging to them than other activities."

\section{Student Learning}

Across surveys and module feedback, teachers reported a theme of 'deeper learning' as a major benefit students gained from participating in the XAL modules. 'Deeper learning' can be thought of as "the process through which an individual becomes capable of taking what was learned in one situation and applying it to new situations" (NRC 2012, p. 5) which can be supported in an environment "in which students gain content knowledge and also develop intrapersonal and interpersonal competencies" (NRC 2012, p. 7). While some teachers indicated deeper learning by stating simply that through the modules "students were better able to understand" a given concept, we were able to trace aspects of deeper learning (content knowledge, inter-and intrapersonal skills) across the data.

\section{Content knowledge:}

Teachers were asked to indicate what percentage of their students met proficiency on learning objectives for each module, based on pre-and post-module assessments. It is important to note that of the 21 total post-survey respondents for the Waterways and Animal Nutrition modules, less than half were able to report student proficiency due to lack of data (either teachers were unable to implement assessments or because they solely reviewed module content). However, of teachers who were able to report on this metric, they reported $83 \%$ or more of their students met the learning objectives across all three modules (as displayed in Figure 4), with Animal Nutrition reaching a slightly higher percentage at $88 \%$ of student meeting learning objectives.

\footnotetext{
${ }^{3}$ Parent feedback was not solicited as part of this study, and may be biased, as these parents selectively decided to send feedback to teachers.
} 
Figure 4. The average percentage of students that met the learning objectives for each module, based on teacher-implemented assessment.

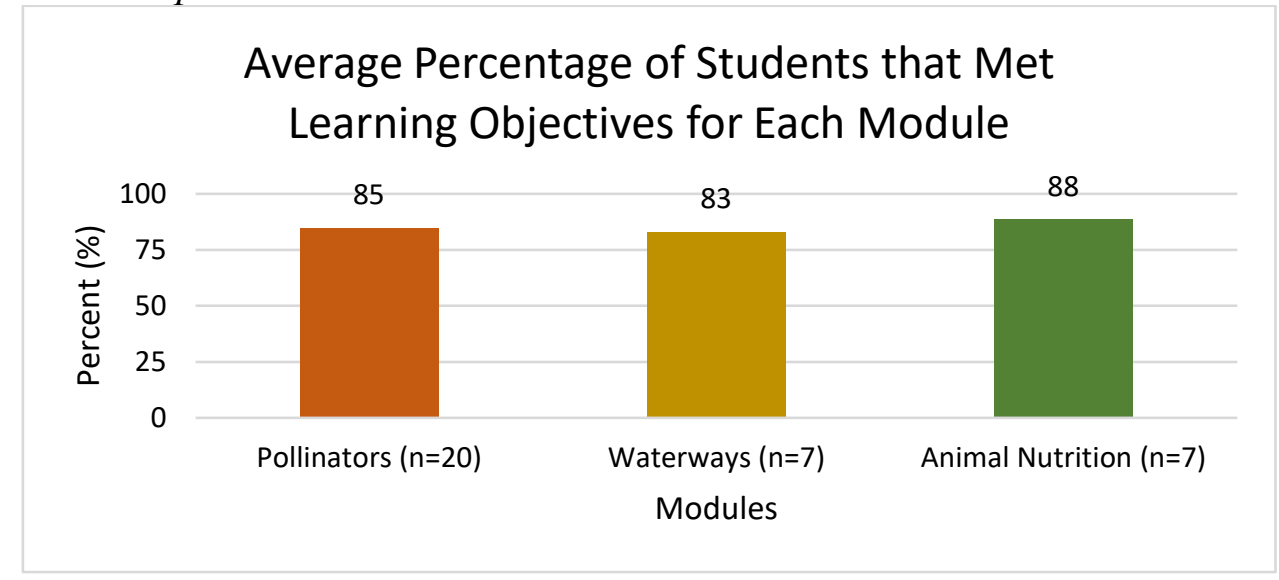

These percentages are certainly encouraging. We did, however, receive some indication from teacher suggestions that, particularly for the Pollinator and Waterways modules, students (and teachers) could have benefitted from more thorough background information to support students' learning and exploration. Teachers also suggested some module content could be modified to better suit grade-level, especially as related to $\mathrm{K}$ students. This also echoes concerns that were raised in the earlier study where teachers raised concern about whether some of the videos, especially in the Orchids module, was developmentally appropriate for young learners. The feedback also suggests that teachers are interested in co-creating and co-developing materials and could be a useful resource for vetting materials to ensure they are grade-level appropriate for early elementary learners.

"Building background before or after the modifications needs to occur if the focal point is the design aspect of the modules."

"I think the waterways lessons could have been great for third grade students but don't think it was entirely appropriate for kindergarten students."

In the module feedback surveys, overall, teachers 'Agree' that each module helped students learn key scientific concepts, as shown in Figure 5 ('Agree' is a ranking of 4, based on a scale from ' 1 ' meaning 'Strongly Disagree' to ' 5 ' meaning 'Strongly Agree'). This rating is supported by teachers' free responses - teachers frequently commented on students' grasp of the module content. And numerous teachers went a step further to describe in what ways the module structures facilitated this knowledge-attainment.

The 'what':

Students learned "how animal poop can tell us a lot about an animal." 
"They were more aware or made aware of water health, organisms present in the waterways, and the seining process."

The 'how':

"Through the more detailed and thorough interaction with the material students were able to gain a deeper understanding of the topic."

The modules allowed students to "apply content knowledge to real life experiences"

Figure 5. Teachers rated the extent to which they agreed with the statement 'This module helped students learn key scientific concepts.'

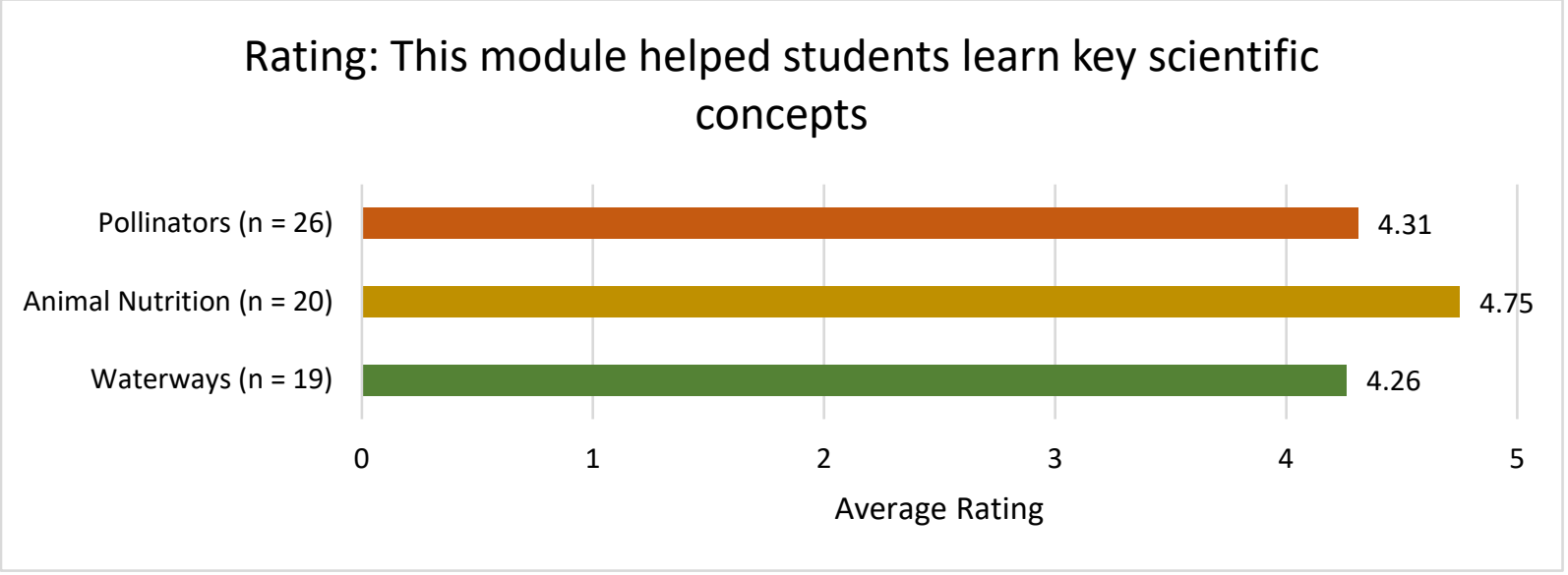

\section{Science and Engineering Practices:}

Along with content knowledge, teachers described the extent to which the modules facilitated deeper learning through support of science and engineering practices such as questioning and explaining through discussion. Overall, teachers reported that they 'Agree' that the modules developed students' questioning skills, as shown in Figure 6. This rating is reinforced with explanations that the module design supported question-asking and open-ended discussion.

The Pollinator module "allowed them to create their own questions, share their questions with peers, and then create more questions...."

"The students were incredibly curious and so interested in the activities. They were constantly wondering and asking questions during their explorations."

The "questions we formulated as a group were open-ended and they were able to explore with materials while creating scat ... they also continued to question one another..."

"They were asking more 'I wonder' questions." 
Figure 6. Teachers rated the extent to which they agreed with the statement 'The module developed students' questioning skills'.

\section{Rating: The module developed students' questioning skills}

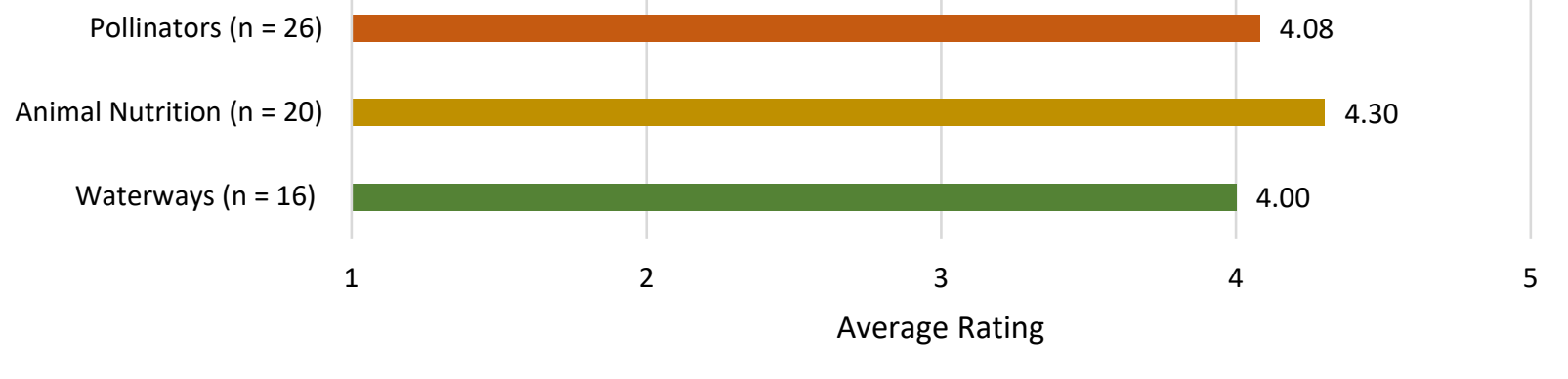

Teachers reported whether or not students engaged in, or would have engaged in, the eight science and engineering practices outlined in the NGSS through the XAL modules. As shown in Table 10, all teachers reported that their class engaged in at least some of the science and engineering practices. Across all three modules, the most prevalent practices were planning and carrying out investigations, asking questions and defining problems, constructing explanations and designing solutions, and developing and using module solutions. In other words, the majority of classes engaged in half of the science and engineering practices. The least well represented practice was using mathematical and computational thinking. This aligns with the previously discussed finding that teachers experienced little change in their confidence in supporting students' mathematical and computational thinking skills.

Table 10. Percent of classes that engaged in or would have engaged in each science and engineering practice.

\begin{tabular}{|l|r|r|r|}
\hline Science and Engineering Practice & Pollinators & Animal Nutrition & Waterways \\
\hline Planning and carrying out investigations & $\mathbf{8 8 \%}$ & $\mathbf{8 0 \%}$ & $\mathbf{9 5 \%}$ \\
\hline Asking questions and defining problems & $\mathbf{8 5 \%}$ & $\mathbf{9 0 \%}$ & $\mathbf{8 4 \%}$ \\
\hline $\begin{array}{l}\text { Constructing explanations and designing } \\
\text { solutions }\end{array}$ & $\mathbf{7 3 \%}$ & $\mathbf{9 0 \%}$ & $\mathbf{7 4 \%}$ \\
\hline $\begin{array}{l}\text { Obtaining, evaluating, and communicating } \\
\text { information }\end{array}$ & $35 \%$ & $\mathbf{8 5 \%}$ & $\mathbf{5 3 \%}$ \\
\hline Analyzing and interpreting data & $35 \%$ & $\mathbf{5 5 \%}$ & $\mathbf{7 9 \%}$ \\
\hline Engaging in argument from evidence & $38 \%$ & $35 \%$ & $32 \%$ \\
\hline $\begin{array}{l}\text { Using mathematical and computational } \\
\text { thinking }\end{array}$ & $27 \%$ & $25 \%$ & $37 \%$ \\
\hline Developing and using module solutions & $\mathbf{5 0 \%}$ & $\mathbf{8 5 \%}$ & $\mathbf{5 3 \%}$ \\
\hline $\begin{array}{l}\text { I do not think students engaged in any science } \\
\text { or engineering practices }\end{array}$ & $0 \%$ & $0 \%$ & $0 \%$ \\
\hline
\end{tabular}


Teachers were asked to elaborate or share an example of how the module helped them address science and engineering practices. Many of the explanations captured the layers of cognitive processes involved in student's engagement with the modules.

"The students . . used planning and discussion to make their new insect that was pollution tolerate and tried to design how to help the pollution. They reflected on their work and made adjustments as they received feedback from their peers." (Planning and Carrying Out Investigations, Constructing Explanations and Designing Solutions, Obtaining, Evaluating and Communicating Information; Waterways)

"Students were able to conduct research and share that research with others. They are writing argumentative pieces to support why the flower they designed would be able to survive in the biome they studied." (Obtaining, Evaluating, and Communicating Information; Analyzing and Interpreting Data; Engaging in Argument from Evidence; Pollinators)

"Students loved searching for and investigating classmates animal scat samples. In doing so, they discussed with partners what they noticed about the scat, what that animal could have eaten, and then drawing conclusions about what animal it could have been or not been. . . . Their discussions upon finding scat, led to sketches, analysis, and further research about which animal and what it ate." (Planning and Carrying Out Investigations; Asking Questions and Defining Problems; Constructing Explanations and Designing Solutions; Analyzing and Interpreting Data; Animal Nutrition)

\section{Interpersonal and Intrapersonal:}

Fostering deeper learning also involves development of inter-and intrapersonal competenciesthe ways in which learners interact with others (e.g. teamwork and collaboration) and self (e.g. self-direction, adaptability, self-reinforcement) (NRC 2012). While teachers were not asked about these concepts specifically, both emerged as themes in teachers' free responses.

When teachers were asked how, if at all, students benefited from engaging with the modules, a theme of collaboration emerged. For instance, "students had to work together" to make decisions in their design process, students "inquire[d] of each other", "made adjustments as they received feedback from peers" and "learned how to listen well" while classmates were sharing.

When teachers were asked how, if at all, students benefited from engaging with the modules, a theme of student-led learning or self-direction emerged. Teachers noted that the module structure creates an atmosphere in which students "are enjoying the ability to explore, research, and 
create. It has given them ownership over their own learning." That not only were students learning content, but were able to "create their own questions, and find their own answers" and "learn what it takes to think for themselves".

\section{Study Conclusions and Recommendations}

This evaluation study aimed to build upon previous phases by expanding the sample of $\mathrm{K}$ and $3^{\text {rd }}$ grade teachers engaged in this implementation phase. While unable to recruit teachers from the Cincinnati area, the sample of teachers was expanded to include diverse schools and student populations across the Greater Columbus and Cleveland areas. Overall, in this latest iteration of implementation, the Explorer At Large materials continued to garner positive teacher feedback.

The overall study conclusions are organized here by each of the overarching research questions.

Question $1 \& 2$ : Will Kindergarten and $3^{\text {rd }}$ grade teachers consider the XAL instructional units to be valuable overall and valuable for student learning, engagement, and questionsasking skill development? Will Kindergarten and 3rd grade teachers be able to successfully include instructional units of varying length based on one or more XAL videos in their classrooms and in what ways?

- The findings support that teachers generally consider the instructional units to be valuable for their students' engagement ('hands-on' activities) and deeper learning (content knowledge, engaging students in science and engineering practices, and developing their inter/intrapersonal skills), with, however, room for growth in development of questioning skills and mathematical/computational thinking. Teachers also indicated additional background information (for teachers and students) and some modifications to enhance age-appropriateness could further support engagement and students reaching learning objectives.

- The findings also show that the XAL modules offered teachers flexibility in how and when they implemented the materials, to meet their needs, with few technical difficulties.

- Generally, the Animal Nutrition module received consistently higher value ratings and positive feedback than the other two modules.

Question 3: Will Kindergarten and 3rd grade teachers who utilize these instructional units make changes to their own instructional practices and show changes in self-efficacy teaching exploration and discovery-based classroom units?

- Before and after implementing the XAL material, teachers showed some shifts in their instructional practices, as related to certain science topics, lesson preparation/implementation processes, and student engagement. 
- Teachers' self-efficacy in supporting science and engineering practices showed significant increase over the course of the XAL program. Teacher showed little shift in their confidence as related to promoting Knowledge-Seeking Skills, engaging students in asking questions or helping students in using mathematical/computational thinking.

Question 4: Will teachers report that Kindergarten and $3^{\text {rd }}$ grade students show growth on fundamental measures of affective and cognitive learning associated with the exploratory nature of the XAL modules?

- Generally, teachers found that materials and associated activities to be highly engaging for students, especially the videos and materials associated with the Animal Nutrition module.

- The modules were generally effective at engaging students with science concepts and teachers reported high levels of student proficiency following implementation of each module.

- For the most part, the materials were successful at engaging students with scientific practices and deeper learning.

\section{Recommendations}

Within the overall favorable feedback from this implementation phase, arose opportunities to further develop the XAL program in preparation for future iterations of the program. In the following section, we provide a few recommendations based on suggests from participating teachers and insights that emerged from the data.

\section{Continue Developing XAL Content and Material}

- Exemplar module: Teachers rated all modules as valuable, though across metrics, the Animal Nutrition module performed better than the other two. We suggest using the Animal Nutrition module as an exemplary module and drawing from its successes to further iterate and develop the other two modules, future modules as well as other expects of the XAL ecosystem (e.g., Family Moments).

- Building background: While student engagement in the modules was generally high, teachers suggested that incorporating more background information or material to help preface the modules would ease student entry into the module content, whether this comes in the form of reading list, links, or introductory videos. Teachers also suggested incorporating background content for teachers to learn more about the specific topics. Many of these comments pertained specifically to the Pollinator and Waterways modules, which helps indicate specific areas for improvement.

- Teacher co-design: Again, teachers enjoyed the overall flexibility of the modules to be adapted for their classroom. There were some aspects of the module activities, as teachers noted, that were less easily adaptable. For instance, teachers reported some issues with age-appropriateness for Kindergarteners and disconnect with state standards in the 
Pollinator and Waterways modules that were difficult to mediate. This suggests an opportunity to continue developing module content in coordination with teachers, in a collaborative design process.

- Question Asking and Curiosity: On the whole, students met learning objectives of the modules and showed signs of deeper learning (through teacher feedback). Teachers reported on student excitement, engagement in the modules and science practices. However, there appears to be some room for improvement in areas of developing question-asking skills and fostering student curiosity. This suggests a need for additional tools or strategies to support teachers in these areas or rethinking how the structure of the modules could better support students and teachers in question-asking and curiosity.

\section{Expanded Recruitment Strategies}

- Recruitment: In this implementation phase, we aimed to recruit teachers and classrooms across a greater geographical area, including Cleveland, Columbus and Cincinnati. While we able to recruit a large number of teachers from Columbus, we recruited only a few teachers from Cleveland and no teachers from Cincinnati. This suggests a need for a more robust recruitment strategy. For instance, recruiting and deploying stipendsupported teacher 'champions' in each area could be a strategy for recruiting more teachers in target communities. 


\section{References}

National Research Council 2012. Education for Life and Work: Developing Transferable Knowledge and Skills in the 21st Century. Washington, DC: The National Academies Press. https://doi.org/10.17226/13398. 


\title{
APPENDIX A: Data Collection Instruments
}

\section{Default Question Block}

\author{
Pilot Teacher Pre-Survey. \\ - Explorer At Large Pilot Study -
}

Thank you for your participation in the Explorer At Large $(X A L)$ project and evaluation! This presurvey will help us to know a little bit more about you as a teacher and your teaching context.

\section{XAL Program Evaluation}

Overview: Evaluators from Oregon State University are collaborating with Explorer At Large (XAL) and the PAST Foundation to gather teachers' feedback to improve the resources and to learn more about your experience implementing the videos and associated instructional models.

Confidentiality: The responses you provide on surveys throughout the study will only be accessible to the evaluation team at Oregon State University. We may share de-identified data with project partners at Explorer At Large or the PAST Foundation so that we may jointly make sense of the data and co-interpret the results. Your name and other identifying information would be removed before we share with partners.

Study Contact: If you have any questions about this evaluation study, please contact Dr. Kelly Riedinger (Kelly.riedinger@oregonstate.edu).

What questions can we answer for you about the evaluation study?

Last name:

First name

In what grade level will you be implementing the XAL modules?

$\square$ Kindergarten

3rd Grade

How many years have you been a teacher (not including this academic year)? 
This is my first-year teaching

$1-2$

3-5

6-10

$11-20$

More than 20 years

What is the total combined number of students in your class(es)?

Please estimate the percentage (\%) of students in your class(es) this academic year (20192020) who:

$0 \quad$ Are English Language Learners

$0 \quad$ Qualify for free or reduced lunch

$0 \quad$ Are identified as special needs or special education students

Have you ever participated in a PAST Foundation professional development workshop or online meeting prior to this project?

Y Yes

No

In all, how many PAST Foundation workshops or meetings have you participated in prior to this project?

For each of the items below, please rate your current level of confidence on a scale from 1 to 5 where " 1 " is "Cannot do at all" and " 5 " is "Highly certain I can do it."

\begin{tabular}{|c|c|c|c|c|c|}
\hline & $\begin{array}{l}1 \text { - Cannot } \\
\text { do it at all }\end{array}$ & 2 & $\begin{array}{c}3 \text { - } \\
\text { Moderately } \\
\text { confident I } \\
\text { can do it }\end{array}$ & 4 & $\begin{array}{c}5 \text { - Highly } \\
\text { certain I can } \\
\text { do it }\end{array}$ \\
\hline $\begin{array}{l}\text { Encourage students } \\
\text { to be persistent }\end{array}$ & 0 & 0 & 0 & 0 & 0 \\
\hline
\end{tabular}




\begin{tabular}{|c|c|c|c|c|c|}
\hline & $\begin{array}{l}1 \text { - Cannot } \\
\text { do it at all }\end{array}$ & 2 & $\begin{array}{c}3 \text { - } \\
\text { Moderately } \\
\text { confident I } \\
\text { can do it }\end{array}$ & 4 & $\begin{array}{l}5 \text { - Highly } \\
\text { certain I can } \\
\text { do it }\end{array}$ \\
\hline Motivate students & 0 & 0 & 0 & 0 & 0 \\
\hline $\begin{array}{l}\text { Foster students' } \\
\text { curiosity }\end{array}$ & 0 & 0 & 0 & 0 & 0 \\
\hline $\begin{array}{l}\text { Encourage students } \\
\text { to explore }\end{array}$ & 0 & 0 & 0 & 0 & 0 \\
\hline $\begin{array}{l}\text { Encourage students' } \\
\text { creativity }\end{array}$ & 0 & 0 & 0 & 0 & 0 \\
\hline $\begin{array}{l}\text { Encourage students } \\
\text { to think critically }\end{array}$ & 0 & 0 & 0 & 0 & 0 \\
\hline $\begin{array}{l}\text { Help students take } \\
\text { control of their } \\
\text { learning }\end{array}$ & 0 & 0 & 0 & 0 & 0 \\
\hline
\end{tabular}

For each of the items below, please rate your current level of confidence on a scale from 1 to 5 where " 1 " is "Cannot do at all" and " 5 " is "Highly certain I can do it."

\begin{tabular}{|c|c|c|c|c|c|}
\hline & $\begin{array}{l}1 \text { - Cannot } \\
\text { do it at all }\end{array}$ & 2 & $\begin{array}{l}3 \text { - } \\
\text { Moderately } \\
\text { confident I } \\
\text { can do it }\end{array}$ & 4 & $\begin{array}{l}5 \text { - Highly } \\
\text { certain I } \\
\text { can do it }\end{array}$ \\
\hline $\begin{array}{l}\text { Engage students in asking } \\
\text { questions }\end{array}$ & 0 & 0 & 0 & 0 & 0 \\
\hline $\begin{array}{l}\text { Help students in developing } \\
\text { and using models }\end{array}$ & 0 & 0 & 0 & 0 & 0 \\
\hline $\begin{array}{l}\text { Help students in planning } \\
\text { and carrying out } \\
\text { investigations }\end{array}$ & 0 & 0 & 0 & 0 & 0 \\
\hline \multirow[t]{2}{*}{$\begin{array}{l}\text { Assisting students in } \\
\text { analyzing and interpreting } \\
\text { data }\end{array}$} & 0 & 0 & 0 & 0 & 0 \\
\hline & $\begin{array}{l}1 \text { - Cannot } \\
\text { do it at all }\end{array}$ & 2 & $\begin{array}{c}3 \text { - } \\
\text { Moderately } \\
\text { confident I } \\
\text { can do it }\end{array}$ & 4 & $\begin{array}{l}5 \text { - Highly } \\
\text { certain I } \\
\text { can do it }\end{array}$ \\
\hline $\begin{array}{l}\text { Help students in using } \\
\text { mathematics and } \\
\text { computational thinking }\end{array}$ & 0 & 0 & 0 & 0 & 0 \\
\hline
\end{tabular}




\begin{tabular}{|c|c|c|c|c|c|}
\hline & $\begin{array}{l}1 \text { - Cannot } \\
\text { do it at all }\end{array}$ & 2 & $\begin{array}{c}3 \text { - } \\
\text { Moderately } \\
\text { confident I } \\
\text { can do it }\end{array}$ & 4 & $\begin{array}{l}5 \text { - Highly } \\
\text { certain I } \\
\text { can do it }\end{array}$ \\
\hline $\begin{array}{l}\text { Encourage students to } \\
\text { construct explanations }\end{array}$ & 0 & 0 & 0 & O & 0 \\
\hline $\begin{array}{l}\text { Encourage students to } \\
\text { engage in argument from } \\
\text { evidence }\end{array}$ & 0 & 0 & 0 & 0 & 0 \\
\hline $\begin{array}{l}\text { Encourage students to } \\
\text { obtain, evaluate and } \\
\text { communicate information }\end{array}$ & 0 & 0 & 0 & 0 & 0 \\
\hline
\end{tabular}




\section{Pilot Module Feedback Form Adjusted}

- For Teachers -

We thank you again for participating in the Explorer At Large pilot program. We understand that due to unexpected circumstances you likely have not been able to fully implement all three modules in the classroom as intended.

As part of the Explorer At Large pilot program, we still expect to receive your feedback on all three modules and complete a post-program survey after you have either implemented all of the resources via distance learning or reviewed and provided feedback on each module. We anticipate that some teachers may have implemented some of the modules in the classroom and some modules via distance learning (if you opted to do so). We also understand that there may be one or more modules that you will not have the opportunity to implement at all. In this case, we ask that you please provided provide feedback on those modules based on your engagement with the module content during the workshop (if you attended) and your professional review as a teacher.

We have adjusted the feedback survey to be flexible and enable you to provide feedback on the modules in whichever way best fits your experience--whether you implemented some modules in the classroom, some via distance learning and/or reviewed the modules.

Please feel free to reach out to the evaluation team at any time with questions or concerns.

$-$

Last name:

First name:

For which instructional module are you providing feedback? 
Please note: we'll need you to fill out one survey per module. If you need to provide feedback on more than one module today, you can do so by finishing this survey and hitting the "refresh" button in your browser.
Waterways
O Pollinators
Animal Nutrition

Which of the following most accurately describes your experience with the $\$\{q: / / Q I D 2 / C h o i c e G r o u p / S e l e c t e d C h o i c e s\}$ module?
I fully implemented the module in the classroom
I partially implemented the module in the classroom
○ fully implemented the module via distance learning
I partially implemented the module via distance learning
I reviewed the module material, but did not implement the module

\section{Experiential Feedback}

In what grade did you implement the $\$\{\mathrm{q}: / / \mathrm{QID} 2 /$ ChoiceGroup/SelectedChoices $\}$ module? (Please select all that apply.)
Kindergarten
3rd grade

Altogether, please estimate approximately how long you spent implementing the $\$\{q: / / Q I D 2 / C h o i c e G r o u p / S e l e c t e d C h o i c e s\}$ module with your students. Please round your answer to the nearest quarter hour.
0
Hours

Which of the following videos from the $S\{q: / / Q I D 2 / C h o i c e G r o u p / S e l e c t e d C h o i c e s\}$ module did you use with students? (Please select all that apply.)

$\square$ sI Gardens

$\square$ Orchids

Lion Nutrition

Lion Poop 


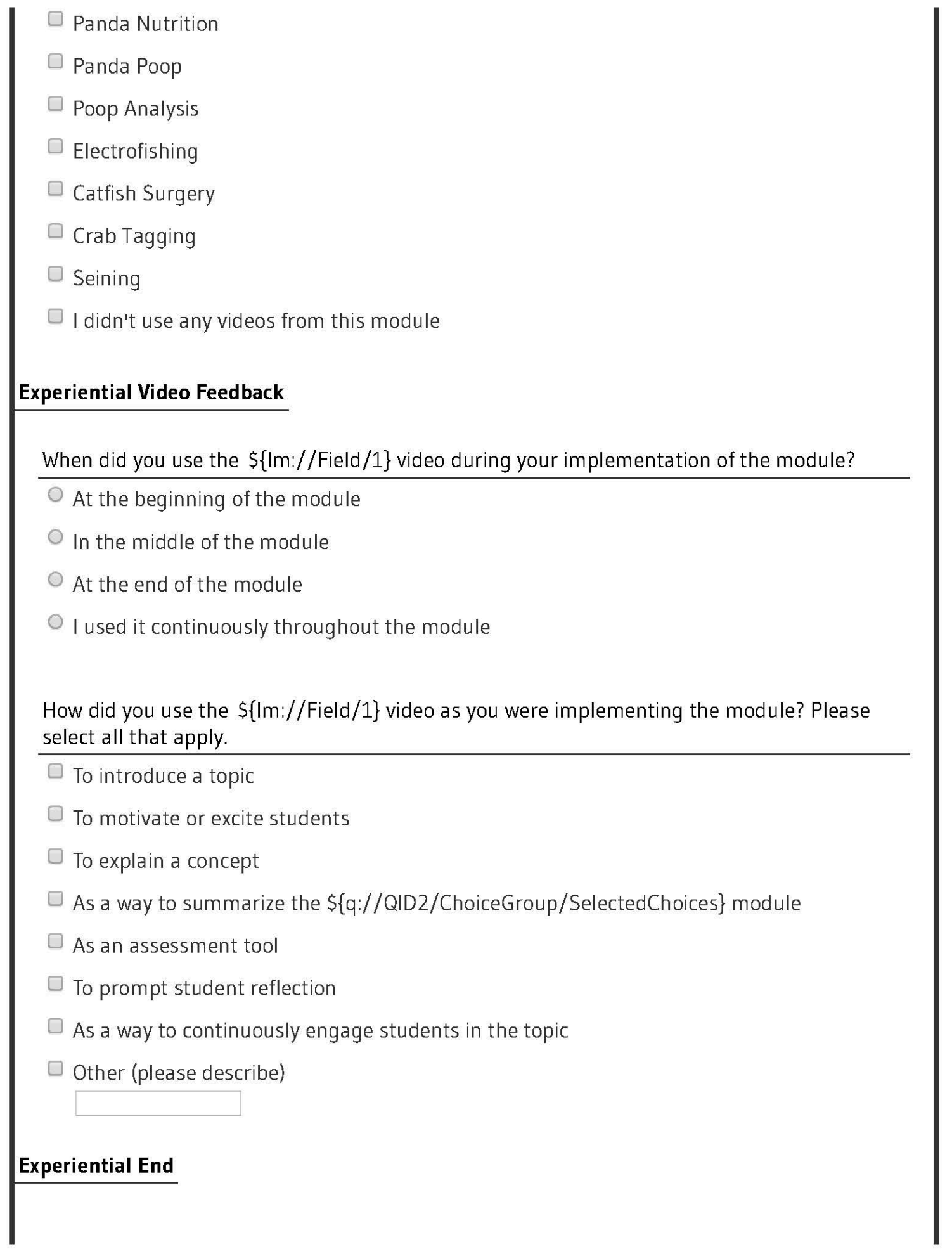


Did you use the $\$\{q: / / Q I D 2 / C h o i c e G r o u p / S e l e c t e d C h o i c e s\}$ module as suggested or did you make changes?

I implemented the entire module as suggested

I only implemented a portion of the module, but did so as suggested

I made changes to the module

Briefly describe any modifications you made to the instructional module.

Briefly describe why you had to make changes to the instructional module.

Overall, how satisfied were you with the $\$\{q: / / Q 1 D 2 / C h o i c e G r o u p / S e l e c t e d C h o i c e s\}$ module? Please use a scale from 1 to 10 where " 1 " is "Not at all satisfied" and " $10^{\prime \prime}$ is "Very satisfied."

$\begin{array}{cccccccccc}1 & 2 & 3 & 4 & 5 & 6 & 7 & 8 & 9 & 10 \\ 0 & 0 & 0 & 0 & 0 & 0 & 0 & 0 & 0 & 0\end{array}$

How likely are you to use the $\$\{q: / / Q I D 2 / C h o i c e G r o u p / S e l e c t e d C h o i c e s\}$ module in the future? Please use a scale from 1 to 10 where " 1 " is "Not at all likely" and " $10^{\prime \prime}$ is "Very likely."

$\begin{array}{llllllllll}1 & 2 & 3 & 4 & 5 & 6 & 7 & 8 & 9 & 10 \\ 0 & 0 & 0 & 0 & 0 & 0 & 0 & 0 & 0 & 0\end{array}$

How likely are you to recommend the $\$\{q: / / Q I D 2 / C h o i c e G r o u p / S e l e c t e d C h o i c e s\}$ module to a colleague? Please use a scale from 1 to 10 where " 1 " is "Not at all likely" and " 10 " is "Very likely."

$\begin{array}{cccccccccc}1 & 2 & 3 & 4 & 5 & 6 & 7 & 8 & 9 & 10 \\ 0 & 0 & 0 & 0 & 0 & 0 & 0 & 0 & 0 & 0\end{array}$

In what ways, if at all, do you think your students benefited from your implementation of the $\$\{q: / / Q 1 D 2 / C h o i c e G r o u p / S e l e c t e d C h o i c e s\}$ module?

With which of the following science and engineering practices did students engage as a result of implementing the $\$\{q: / / Q I D 2 / C h o i c e G r o u p / S e l e c t e d C h o i c e s\}$ module? (Please select all 
that apply.)

$\square$ Asking questions and defining problems

Developing and using module solutions

Planning and carrying out investigations

$\square$ Analyzing and interpreting data

I do not think students engaged in any science or engineering practices

Using mathematical and computational thinking

Constructing explanations and designing solutions

Engaging in argument from evidence

$\square$ Obtaining, evaluating, and communication information

Please explain or share an example of how the $\$\{q: / / Q I D 2 / C h o i c e G r o u p / S e l e c t e d C h o i c e s\}$ module helped you address the science and engineering practice(s)?

To what extent do you agree with the following statement:

The $\$\{q: / / Q I D 2 / C h o i c e G r o u p / S e l e c t e d C h o i c e s\}$ module helped students learn key scientific concepts.

$\begin{array}{ccccc}1 \text { - Strongly } & 3 \text { - Neither agree } \\ \text { disagree } & 2 & \text { nor disagree } & 4 & 5 \text { - Strongly agree } \\ 0 & 0 & 0 & 0 & 0\end{array}$

Please elaborate or share an example of how the $\$\{q: / / Q I D 2 / C h o i c e G r o u p / S e l e c t e d C h o i c e s\}$ module helped students learn the science concepts.

To what extent do you agree with the following statement:

The $\$\{q: / / Q I D 2 / C h o i c e G r o u p / S e l e c t e d C h o i c e s\}$ module was engaging for my students.

$\begin{array}{ccccc}\begin{array}{c}\text { 1-Strongly } \\ \text { disagree }\end{array} & 2 & \text { 3- Neither agree } & \\ 0 & 0 & \text { nor disagree } & 4 & 5 \text {-Strongly agree }\end{array}$


Please elaborate or share an example of how the $\$\{q: / / Q I D 2 / C h o i c e G r o u p / S e l e c t e d C h o i c e s\}$ module engaged your students.

To what extent do you agree with the following statement:

The $\$\{q: / / Q 1 D 2 / C h o i c e G r o u p / S e l e c t e d C h o i c e s\}$ module developed students questioning skills (e.g., asking questions that are open-ended and have multiple answers, asking questions that lead to an investigation or exploration)?

$\begin{array}{ccccc}1 \text { - Strongly } & 3 \text { - Neither agree } \\ \text { disagree } & 2 & \text { nor disagree } & 4 & 5 \text { - Strongly agree } \\ 0 & 0 & 0 & 0 & 0\end{array}$

Please elaborate or share an example of how the $\$\{q: / / Q I D 2 / C h o i c e G r o u p / S e l e c t e d C h o i c e s\}$ module helped students with their questioning skills.

Overall, what did you think was particularly effective or successful about the $\$\{q: / / Q I D 2 / C h o i c e G r o u p / S e l e c t e d C h o i c e s\}$ module? Why?

If at all, how was your instruction using the modules different from what you would normally do in your classroom?

Did you experience any technical issues while implementing the modules?

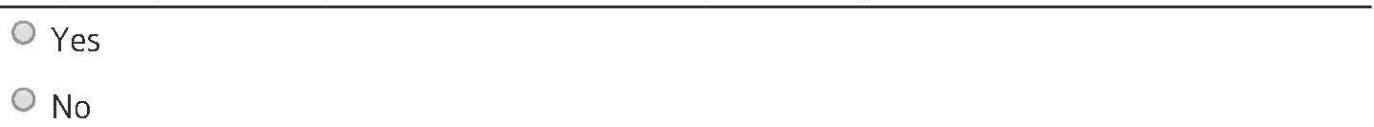

Please indicate what issues you experienced (select all that apply):

$\square$ Video wouldn't load

$\square$ My school blocked the video content

Video froze during viewing

Video play was slow 
Other (Please specify):

What recommendations do you have for improving the $\$\{q: / / Q 1 D 2 / C h o i c e G r o u p / S e l e c t e d C h o i c e s\}$ module?

Is there anything else that you would like to tell us about the $\$\{q: / / Q I D 2 / C h o i c e G r o u p / S e l e c t e d C h o i c e s\}$ that would help other teachers use the resources?

\section{Conceptual Feedback}

In what grade would you have implemented the $\$\{q: / / Q I D 2 / C h o i c e G r o u p / S e l e c t e d C h o i c e s\}$ module? (Please select all that apply.)
$\square$ Kindergarten
$\square$ 3rd grade

Please estimate approximately how long you think it would have taken to implement the $\$\{q: / / Q I D 2 / C h o i c e G r o u p / S e l e c t e d C h o i c e s\}$ module with your students. Please round your answer to the nearest quarter hour.

0 Hours

\section{Conceptual Concluding Feedback}

Would you have used the $\$\{q: / / Q I D 2 / C h o i c e G r o u p / S e l e c t e d C h o i c e s\}$ module as suggested or would you likely have made changes?

I would have likely implemented the entire module as suggested

I would have likely only implemented a portion of the module, but would have done so as suggested

I would likely have made changes to the module

Briefly describe any modifications you would have made to the instructional module. 
Briefly describe why you would have made changes to the instructional module.

Based on your review, how satisfied were you with the $\$\{q: / / Q I D 2 / C h o i c e G r o u p / S e l e c t e d C h o i c e s\}$ module? Please use a scale from 1 to 10 where " 1 " is "Not at all satisfied" and " 10 " is "Very satisfied."

$\begin{array}{cccccccccc}1 & 2 & 3 & 4 & 5 & 6 & 7 & 8 & 9 & 10 \\ 0 & 0 & 0 & 0 & 0 & 0 & 0 & 0 & 0 & 0\end{array}$

How likely are you to use the $\$\{q: / / Q I D 2 / C h o i c e G r o u p / S e l e c t e d C h o i c e s\}$ module in the future? Please use a scale from 1 to 10 where " 1 " is "Not at all likely" and " 10 " is "Very likely."

$\begin{array}{cccccccccc}1 & 2 & 3 & 4 & 5 & 6 & 7 & 8 & 9 & 10 \\ 0 & 0 & 0 & 0 & 0 & 0 & 0 & 0 & 0 & 0\end{array}$

How likely are you to recommend the $\$\{q: / / Q I D 2 / C h o i c e G r o u p / S e l e c t e d C h o i c e s\}$ module to a colleague? Please use a scale from 1 to 10 where " 1 " is "Not at all likely" and " 10 " is "Very likely."

$\begin{array}{cccccccccc}1 & 2 & 3 & 4 & 5 & 6 & 7 & 8 & 9 & 10 \\ 0 & 0 & 0 & 0 & 0 & 0 & 0 & 0 & 0 & 0\end{array}$

With which of the following science and engineering practices do you think students would engage with as a result of implementing the $\$\{q: / / Q I D 2 / C h o i c e G r o u p / S e l e c t e d C h o i c e s\}$ module? (Please select all that apply.)

$\square$ Asking questions and defining problems

Developing and using module solutions

Planning and carrying out investigations

Analyzing and interpreting data

I do not think students would engage in any science or engineering practices

Using mathematical and computational thinking

Constructing explanations and designing solutions

Engaging in argument from evidence

Obtaining, evaluating, and communication information 
To what extent do you agree with the following statement:

The \$\{q://QID2/ChoiceGroup/SelectedChoices\} would module help students learn key scientific concepts.

$\begin{array}{ccccc}1 \text {-Strongly } & 3 \text { - Neither agree } \\ \text { disagree } & 2 & \text { nor disagree } & 4 & 5 \text { - Strongly agree } \\ 0 & 0 & 0 & 0 & 0\end{array}$

To what extent do you agree with the following statement:

The $\$\{\mathrm{q}: / /$ QID2/ChoiceGroup/SelectedChoices\} module would be engaging for my students.

$\begin{array}{ccccc}\begin{array}{c}\text { 1- Strongly } \\ \text { disagree }\end{array} & 2 & 3 \text { - Neither agree } & & \\ 0 & 0 & \text { nor disagree } & 4 & 5 \text { - Strongly agree } \\ & 0 & 0 & 0 & 0\end{array}$

To what extent do you agree with the following statement:

The $\$\{q: / / Q I D 2 / C h o i c e G r o u p / S e l e c t e d C h o i c e s\}$ module would help develop students' questioning skills (e.g., asking questions that are open-ended and have multiple answers, asking questions that lead to an investigation or exploration)?

$\begin{array}{ccccc}1 \text { - Strongly } & 3 \text { - Neither agree } \\ \text { disagree } & 2 & \text { nor disagree } & 4 & 5 \text { - Strongly agree } \\ 0 & 0 & 0 & 0 & 0\end{array}$

Overall, what do you think would be particularly effective or successful about the $\$\{q: / / Q I D 2 / C h o i c e G r o u p / S e l e c t e d C h o i c e s\}$ module? Why?

If at all, how do you think your instruction using the module would be different from what you would normally do in your classroom?

What recommendations do you have for improving the $\$[q: / / Q I D 2 / C h o i c e G r o u p / S e l e c t e d C h o i c e s\}$ module?

Is there anything else that you would like to tell us about the $\$\{q: / / Q I D 2 / C h o i c e G r o u p / S e l e c t e d C h o i c e s\}$ that would help other teachers use the 


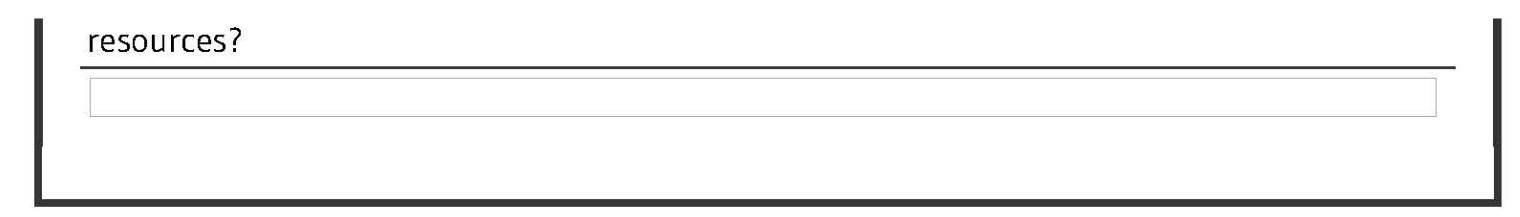




\title{
Default Question Block
}

\section{Pilot Teacher Post-Survey.}

- Explorer At Large Pilot Study -

Hello!

Thank you again for participating in the Explorer At Large (XAL) pilot evaluation study. This short survey is your last task and should take you, at most, 10 minutes to complete. Some of these questions may look familiar. We are trying to understand your experiences participating in Explorer At Large.

Please respond as best as you can, as we understand that some modules were implemented in full or in part in the classroom or distance learning or were not implemented but were reviewed instead. Thank you!

Last name:

First name:

Overall, how valuable were the XAL instructional modules as a collection of resources to your science teaching? Please use a scale from 0 to 10 where " 0 " is "Not at all valuable" and " 10 " is "Highly valuable."

Not valuable at all

$$
0
$$

12

23

○

$$
0
$$

○

How likely are you to use the XAL materials in the future? Please use a scale from 0 to 10 where " 0 " is "Not at all likely" and " $10^{\prime \prime}$ is "Very likely."

Not at all likely

$$
0
$$

$$
1
$$

2

3

\begin{abstract}
4
\end{abstract}
5

6

Highly valuable

○

0

0

○ 
How likely are you to recommend the XAL materials to a colleague? Please use a scale from 0 to 10 where " 0 " is "Not at all likely" and " 10 " is "Very likely."

Not at all likely

01

12

23

34

5

$5 \quad 6$

$6 \quad 7$

Very likely

○

O

0

Please elaborate on your ratings from the three questions above.

In what ways do you think your students were/would have been impacted or benefited from the use of the XAL videos and instructional materials in your classroom or via distance learning? Please elaborate or share an example of how your students benefited or would have benefited.

From the pre- and post-assessments you completed for each of the instructional modules, what percentage of your students met proficiency on the learning objectives? Please select 'Not Applicable' if you were unable to gather proficiency assessment information.

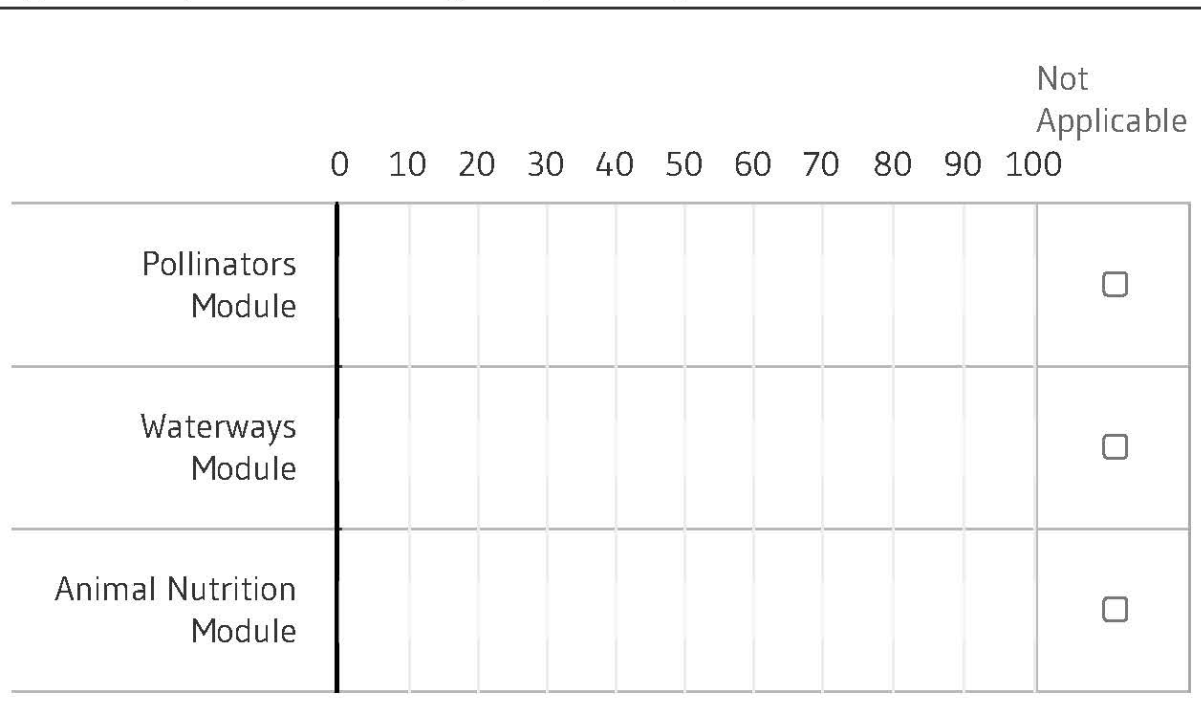

For each of the items below, please rate your current level of confidence on a scale from 1 to 5 where " 1 " is "Cannot do at all" and " 5 " is "Highly certain I can do it." 


\begin{tabular}{|c|c|c|c|c|c|}
\hline & $\begin{array}{l}1 \text { - Cannot } \\
\text { do it at all }\end{array}$ & 2 & $\begin{array}{l}3 \text { - } \\
\text { Moderately } \\
\text { confident I } \\
\text { can do it }\end{array}$ & 4 & $\begin{array}{c}5 \text { - Highly } \\
\text { certain I car } \\
\text { do it }\end{array}$ \\
\hline $\begin{array}{l}\text { Encourage students } \\
\text { to be persistent }\end{array}$ & 0 & 0 & 0 & 0 & 0 \\
\hline Motivate students & 0 & 0 & 0 & 0 & 0 \\
\hline $\begin{array}{l}\text { Foster students' } \\
\text { curiosity }\end{array}$ & 0 & 0 & 0 & 0 & 0 \\
\hline $\begin{array}{l}\text { Encourage students } \\
\text { to explore }\end{array}$ & 0 & 0 & 0 & 0 & $\mathrm{O}$ \\
\hline $\begin{array}{l}\text { Encourage students' } \\
\text { creativity }\end{array}$ & 0 & 0 & 0 & 0 & 0 \\
\hline $\begin{array}{l}\text { Encourage students } \\
\text { to think critically }\end{array}$ & 0 & 0 & $\mathrm{O}$ & 0 & 0 \\
\hline $\begin{array}{l}\text { Help students take } \\
\text { control of their } \\
\text { learning }\end{array}$ & 0 & 0 & 0 & 0 & 0 \\
\hline \multicolumn{6}{|c|}{$\begin{array}{l}\text { For each of the items below, please rate your current level of confidence on a scale from } 1 \text { to } \\
5 \text { where " } 1 \text { " is "Cannot do at all" and " } 5 \text { " is "Highly certain I can do it." }\end{array}$} \\
\hline & $\begin{array}{l}1 \text { - Cannot } \\
\text { do it at all }\end{array}$ & 2 & $\begin{array}{l}3 \text { - } \\
\text { Moderately } \\
\text { confident I } \\
\text { can do it }\end{array}$ & 4 & $\begin{array}{l}5 \text { - Highly } \\
\text { certain I } \\
\text { can do it }\end{array}$ \\
\hline $\begin{array}{l}\text { Engage students in } \\
\text { asking questions }\end{array}$ & 0 & 0 & 0 & 0 & O \\
\hline $\begin{array}{l}\text { Help students in } \\
\text { developing and using } \\
\text { models }\end{array}$ & 0 & 0 & 0 & 0 & 0 \\
\hline $\begin{array}{l}\text { Help students in planning } \\
\text { and carrying out } \\
\text { investigations }\end{array}$ & 0 & 0 & 0 & 0 & 0 \\
\hline \multirow[t]{2}{*}{$\begin{array}{l}\text { Assisting students in } \\
\text { analyzing and } \\
\text { interpreting data }\end{array}$} & 0 & 0 & 0 & 0 & 0 \\
\hline & $\begin{array}{l}1 \text { - Cannot } \\
\text { do it at all }\end{array}$ & 2 & $\begin{array}{c}3 \text { - } \\
\text { Moderately } \\
\text { confident I } \\
\text { can do it }\end{array}$ & 4 & $\begin{array}{l}5 \text { - Highly } \\
\text { certain I } \\
\text { can do it }\end{array}$ \\
\hline
\end{tabular}




\begin{tabular}{|c|c|c|c|c|c|}
\hline & $\begin{array}{l}1 \text { - Cannot } \\
\text { do it at all }\end{array}$ & 2 & $\begin{array}{l}3 \text { - } \\
\text { Moderately } \\
\text { confident I } \\
\text { can do it }\end{array}$ & 4 & $\begin{array}{l}5 \text { - Highly } \\
\text { certain I } \\
\text { can do it }\end{array}$ \\
\hline $\begin{array}{l}\text { Help students in using } \\
\text { mathematics and } \\
\text { computational thinking }\end{array}$ & 0 & 0 & 0 & 0 & 0 \\
\hline $\begin{array}{l}\text { Encourage students to } \\
\text { construct explanations }\end{array}$ & 0 & 0 & 0 & 0 & 0 \\
\hline $\begin{array}{l}\text { Encourage students to } \\
\text { engage in argument from } \\
\text { evidence }\end{array}$ & 0 & 0 & 0 & 0 & 0 \\
\hline $\begin{array}{l}\text { Encourage students to } \\
\text { obtain, evaluate and } \\
\text { communicate information }\end{array}$ & 0 & 0 & 0 & 0 & 0 \\
\hline
\end{tabular}

For each of the following items below, please indicate if your confidence has changed as a result of participating in the XAL project, on a scale from 1 to 5 where " 1 " is "Decreased" and "5" is "Increased."

\begin{tabular}{l|ccccc}
\hline & $\begin{array}{c}1- \\
\text { Decreased }\end{array}$ & 2 & $\begin{array}{c}3 \text { - Stayed } \\
\text { the same }\end{array}$ & 4 & 5 - Increased \\
\hline $\begin{array}{l}\text { Encourage students } \\
\text { to be persistent }\end{array}$ & 0 & 0 & 0 & 0 & 0 \\
$\begin{array}{l}\text { Motivate students } \\
\begin{array}{l}\text { Foster students' } \\
\text { curiosity }\end{array}\end{array}$ & 0 & 0 & 0 & 0 & 0 \\
$\begin{array}{l}\text { Encourage students } \\
\text { to explore }\end{array}$ & 0 & 0 & 0 & 0 & 0 \\
$\begin{array}{l}\text { Encourage students' } \\
\text { creativity }\end{array}$ & 0 & 0 & 0 & 0 & 0 \\
$\begin{array}{l}\text { Encourage students } \\
\text { to think critically }\end{array}$ & 0 & 0 & 0 & 0 & 0 \\
$\begin{array}{l}\text { Help students take } \\
\text { control of their }\end{array}$ & 0 & 0 & 0 & 0 & 0 \\
learning & & 0 & 0 & 0
\end{tabular}

For each of the following items below, please indicate if your confidence has changed as a result of participating in the XAL project, on a scale from 1 to 5 where " 1 " is "Decreased" and "5" is "Increased." 


\begin{tabular}{|c|c|c|c|c|c|}
\hline & $\begin{array}{c}1 \text { - } \\
\text { Decreased }\end{array}$ & 2 & $\begin{array}{l}3 \text { - Stayed } \\
\text { the same }\end{array}$ & 4 & $\begin{array}{c}5- \\
\text { Increased }\end{array}$ \\
\hline $\begin{array}{l}\text { Engage students in } \\
\text { asking questions }\end{array}$ & 0 & 0 & 0 & 0 & 0 \\
\hline $\begin{array}{l}\text { Help students in } \\
\text { developing and using } \\
\text { models }\end{array}$ & 0 & 0 & 0 & 0 & 0 \\
\hline $\begin{array}{l}\text { Help students in planning } \\
\text { and carrying out } \\
\text { investigations }\end{array}$ & 0 & 0 & 0 & 0 & 0 \\
\hline \multirow[t]{2}{*}{$\begin{array}{l}\text { Assisting students in } \\
\text { analyzing and } \\
\text { interpreting data }\end{array}$} & 0 & 0 & 0 & 0 & 0 \\
\hline & $\begin{array}{c}1 \text { - } \\
\text { Decreased }\end{array}$ & 2 & $\begin{array}{l}3 \text { - Stayed } \\
\text { the same }\end{array}$ & 4 & $\begin{array}{c}5- \\
\text { Increased }\end{array}$ \\
\hline $\begin{array}{l}\text { Help students in using } \\
\text { mathematics and } \\
\text { computational thinking }\end{array}$ & 0 & 0 & 0 & 0 & 0 \\
\hline $\begin{array}{l}\text { Encourage students to } \\
\text { construct explanations }\end{array}$ & 0 & 0 & 0 & 0 & 0 \\
\hline $\begin{array}{l}\text { Encourage students to } \\
\text { engage in argument from } \\
\text { evidence }\end{array}$ & 0 & 0 & 0 & 0 & 0 \\
\hline $\begin{array}{l}\text { Encourage students to } \\
\text { obtain, evaluate and } \\
\text { communicate information }\end{array}$ & 0 & 0 & 0 & 0 & 0 \\
\hline
\end{tabular}

Is there anything else you would like to share with us about your experience using the XAL videos and instructional modules in your classroom, via distance learning and/or from your review? If so, please share below. 